\title{
Why wait? Organizational learning, institutional quality and the speed of foreign market re-entry after initial entry and exit
}

Article

Accepted Version

Creative Commons: Attribution-Noncommercial-No Derivative Works 4.0

Surdu, I., Mellahi, K., Glaister, K. W. and Nardella, G. (2018) Why wait? Organizational learning, institutional quality and the speed of foreign market re-entry after initial entry and exit. Journal of World Business, 53 (6). pp. 911-929. ISSN 10909516 doi: https://doi.org/10.1016/j.jwb.2018.07.008 Available at https://centaur.reading.ac.uk/78471/

It is advisable to refer to the publisher's version if you intend to cite from the work. See Guidance on citing.

To link to this article DOI: http://dx.doi.org/10.1016/j.jwb.2018.07.008

Publisher: Elsevier

All outputs in CentAUR are protected by Intellectual Property Rights law, including copyright law. Copyright and IPR is retained by the creators or other copyright holders. Terms and conditions for use of this material are defined in the End User Agreement. 


\section{CentAUR}

Central Archive at the University of Reading

Reading's research outputs online 


\title{
Why wait? Organizational learning, institutional quality and the speed of foreign market re-entry after initial entry and exit
}

\begin{abstract}
Using a unique dataset of over 1,000 foreign market re-entries by multinational enterprises, we draw on organizational learning and institutional theory perspectives to examine the antecedents of speed of foreign market re-entry into previously exited markets. Contrary to expectations, we find that the length of experience accumulated between initial entry and exit does not lead to earlier re-entries. In turn, the depth of experience accumulated through operating via joint ventures and the nature of the experience determined by the exit process have a significant impact for early re-entrants. Host country institutional quality leads to early re-entry and, under certain circumstances, moderates the relationship between learning from past experiences and re-entry speed. Our findings reveal experience-based learning to be a complex and dynamic process, one highly dependent on the quality of the institutional setting of the firm. Theoretical and practical implications of the paper are discussed, along with directions for future research on international business strategies.
\end{abstract}

Keywords: foreign market re-entry speed; exit; time-out; learning; experience; institutional theory

\section{Introduction}

Notwithstanding the pervasiveness of foreign market re-entry, when and how multinational enterprises (MNEs) return to already exited markets is not yet fully understood (Surdu, Mellahi and Glaister, 2015; 2018b; Vissak and Francioni, 2013; Vissak and Zhang, 2015; Welch and Welch, 2009). Guided by market entry research, we draw on learning and institutional theories to examine how prior experience and the institutional context influence an MNE's speed of foreign market re-entry into an already exited market. Our knowledge of the antecedents of speed of re-entry into a foreign market is informed primarily by research into initial market entry decisions (Chetty, Johanson and Martín-Martín, 2014; García-García, García-Canal and Guillén, 2017; Gaur, Kumar and Singh, 2014; Jiang, Beamish and Makino, 2014; Tan and Mathews, 2015). Grounded in learning theory, the crux of this burgeoning 
literature is that learning - the development of new knowledge or understanding as a result of past experiences which have the potential to impact on the future behaviour of the organisation (Hurley and Hult, 1998, p. 43) - is an important determinant of the MNE's speed of entry into foreign markets (Casillas and Moreno-Menendez, 2014; Surdu, Mellahi and Glaister, 2018b). What is more, different types of experiences are expected to impact international business strategies such as speed of entry depending on whether they accentuate or reduce uncertainties associated with going into a new international market (see also Delios and Henisz, 2003; Gao and Pan, 2010; Hilmersson and Jansson, 2012). Learning enables the MNE to absorb and utilise knowledge acquired through different types of past experiences to better assess the risks and benefits associated with market entry strategies.

A second strand of literature draws on institutional theory to improve our understanding of market entry strategies (Meyer, Estrin, Bhaumik and Peng, 2009; Surdu et al., 2018b). The central tenet of this line of research is that the external, institutional environment takes a "rulelike status" regulating the behaviour of firms and ensuring that they can engage in market transactions without incurring undue costs. These institutions include, for instance, the legal framework, intellectual property rights, protection of investment and their enforcement, and regulatory regimes (North, 1990; see also Levchenko, 2007). We adopt a broad differentiation of institutions into higher or weaker institutional quality environments. We consider environments to be of "high institutional quality" if they reduce the ambiguity associated with the rules which managers should follow when entering a host market. Higher institutional quality - by reducing confusion around what drives firms to successfully comply with host market institutional requirements - drives earlier entry into that market (Gaba, Pan and Ungson, 2002; Hilmersson and Jansson, 2012; Hsu, Chen and D'Arcy, 2017). Conversely, entering environments with "weak institutional quality" translates into greater perceived institutional ambiguity regarding changing trends in core dimensions of the institutional environment which may generate important hazards for the MNE's international expansion strategies, potentially leaving managers unclear about when to enter.

In this study, we extend previous research on the speed of foreign market entry by focusing on re-entry. We contend that the pervasive assumptions on the impact of past experience and institutional quality/ambiguity and speed of entry need to be revised in the context of re-entry because the latter has some unique features that differentiate it from initial entry. As noted earlier, speed of entry is explained 
by learning which refers to the process of "encoding inferences" from past experiences into practices that guide the behavior of the firm (Levitt and March, 1988, p. 320). Yet, we argue that inferences from past experiences obtained in the same market considered for re-entry are different from those made from experiences gained in a different market as is the case in conventional market entry research (Welch and Welch, 2009). Further, the motive for exit and whether the MNE was pushed or voluntarily exited the market will shape how past experience is interpreted which subsequently influences re-entry (Surdu et al., 2018b). Experience accumulated through successes may be different and less impactful on learning from that accumulated through mistakes or failures (Surdu et al., 2018b; Xia, Boal and Delios, 2009; Zeng, Shenkar, Lee and Song, 2013). This is more relevant for re-entrants which have been once unsuccessful and decided to exit, or for re-entrants which have been pushed from a market. Experiences do not take place in a context-free-vacuum. Hence, the interpretation and usefulness of past experiences by MNEs are shaped by the quality of the institutional context within which they operate (Luo and Peng, 1999; Argote and Miron-Spektor, 2011; Hilmersson and Jansson, 2012). MNEs not only find it hard to evoke knowledge gained in weaker quality institutional environments where the rules of the game are ambiguous and laws are applied inconsistently, but they also find it difficult to interpret knowledge gained from such ambiguous environments (Luo and Peng, 1999). In contrast to high quality institutional environments, where the rules of the game are clear and creation, codification and retention of knowledge is relatively structured, in institutionally weak/ambiguous environments (March, 2010), managers revert to informal practices - often implicit and unobservable - and may turn to personal networks to circumvent institutional voids (Mellahi, Frynas, Sun and Siegel, 2016) making it challenging for MNEs to learn from such experiences. We extend the broader market entry literature by examining the ambiguity reduction effects of institutional quality on the relationship between an MNE's past experience and speed of re-entry. We advocate that host institutional ambiguity is likely to account for the variance observed in the choice of international entry strategies such as when to re-enter an exited market.

Guided by research on the role of experience-based learning on MNE expansion (Luo and Peng, 1999), we further differentiate experience according to length of experience, depth of experience and nature of experience. We argue that experience may not always speed up re-entry. Specifically, we 
argue that length of experience, i.e., how long the MNE operated in the country, depth of experience, i.e. the degree to which the MNE engaged with local stakeholders/actors, and nature of experience, i.e., whether the MNE was forced to exit, have a differentiated impact on the lessons learned by firms which have exited and decided to re-enter. Hence, different types of experiences may influence the speed of re-entry in different ways. Such a fine-grained characterization of experience allows us to answer many previously unanswered questions about how the different types of experiences impact the MNE's speed of international expansion. Do certain types of experiences speed up (re)-entry? Which ones reduce uncertainty and speed up (re)-entry and which ones accentuate it and delay (re)-entry? In addition, how do these experiences interact with the institutional environment to influence speed of (re)-entry?

Taken together, this study makes four contributions. First, it responds to recent calls for expanding the market entry research agenda by looking beyond the current dominant focus on initial foreign market entry, and for redirecting current research efforts towards a more phenomenon-driven perspective (Buckley, Doh and Benischke, 2017; Shaver, 2013; Surdu and Mellahi, 2016; Surdu et al., 2018a). Second, we re-examine prevalent assumptions on the impact of experience-based organisational learning and institutional quality on the speed of foreign market (re)-entry. Third, while previous research has examined the direct impact of past experience and institutional quality, this study also examines their interactive effect on speed of re-entry. We contextualise learning by capturing whether and how stronger institutional quality reduces ambiguity associated with a target market and increases the effectiveness of learning from experiences acquired in that market. Fourth, by unpacking experience into multiple types, we provide a finely grained analysis of the impact of the MNE's past experiences on organizational learning and subsequently on speed of foreign market re-entry. 


\section{Theory and hypotheses}

\subsection{Length of host market experience and re-entry speed}

Acquiring market specific experience is a time-consuming process that narrows the gap between the actual knowledge a firm possesses and the knowledge it needs to reduce the uncertainty associated with the liability of foreignness (Casillas and Moreno-Menendez, 2014; Hilmersson and Jansson, 2012; Zhou and Guillén, 2015). Experience acquired over time becomes embedded in organizational routines and behaviors and thus, firms may find it easier to translate knowledge attained through past experience into learning (Sapienza, Autio, George and Zahra, 2006; Tan, Hung and Liu, 2007).

We contend that, having operated in the host market for a long period of time prior to exit, could lead to earlier re-entries. Our argument here is twofold. First, we argue that prior experiences accumulated over time can translate into increased confidence (March, 1991) in the ability of the firm to operate in the previously exited market. Spending a lengthier period of time in the market gives managers confidence that the firm has accumulated knowledge specific to that market, which increases the ability of the firm to evaluate its external environment (Zhou and Guillén, 2015). Previous studies focusing specifically on the relationships between experience, learning and organizational routines, have confirmed that MNEs which have been international for longer periods of time perceive themselves as being superior at integrating information into their routines and, therefore, more likely to learn (Casillas and Moreno-Menendez, 2014; see also Zhou and Guillén, 2015). For re-entrants, the routines established during the initial entry into the market may be perceived as relevant to that market when the firm decides to re-enter. More experienced re-entrants may not require significant increase in learning opportunities during the time-out period between exit and re-entry, for which reason they may reduce the length of the time-out period by re-entering earlier.

Our second and inter-related argument is that firms may fear that knowledge accumulated from prior experience becomes wasted if they do not re-enter relatively early. The longer firms stay out of the market, the more likely it is that such valuable prior knowledge and experience, such as knowledge attained from network relationships, understanding of consumer preferences, and generally, host market specific experience, will have dissipated (de Holan, Philips and Lawrence, 2004; Cegarra-Navarro and 
Moya, 2005; Tsang and Zahra, 2008). This is problematic because acquiring knowledge through experience is a costly process and that knowledge may be valuable and difficult to obtain by others such as competitors. Spending a long period of time in a market prior to exiting is also a sign of both firm and personal commitment to that market (Eriksson and Chetty, 2003). We propose that re-entrants which have accumulated substantial length of experience during their initial entry, may be keen to reenter the market earlier to leverage that experience. Our first hypothesis is as follows:

Hypothesis 1: The length of host market experience is positively related to speed of re-entry.

\subsection{Depth of host market experience and speed of re-entry}

Depth of host market experience refers to the extent to which the firm acquired highly sophisticated knowledge about a market (Eriksson and Chetty, 2003; García-García et al., 2017). It is well established that depth of experience increases with the resource commitment that firms undertake in a market through the mode of establishment (Barkema and Vermeulen, 1998; Eriksson and Chetty, 2003; GarcíaGarcía et al., 2017). Thus, firms which commit significant resources to host markets through equity investment modes such as wholly owned subsidiaries, are expected to accumulate sophisticated knowledge through broad and rich experiences (Casillas and Moreno-Mendez, 2014; Isobe, Makino and Montgomery, 2000). However, in contrast to length of experience, we advocate that depth of experience accentuates uncertainty and results in delayed re-entries. This is because when managers make a strategic decision such as when to re-enter, they rely not only on the depth of information they possess, but on how the value of their efforts is perceived and rewarded by their organization (Quinn and Cameron, 1988; Smith and Lewis, 2011). Managers interpret their responsibilities within an MNE as a 'psychological contract' with the firm for which they deploy considerable time, effort and other resources (Leonard-Barton, 1992; Quinn and Cameron, 1988). Because depth of experience generally requires significant effort involved in setting up and managing operations in the host market, once the strategies that firms implement are not appropriately recognised or fail, as may be the case with market exit, managers may become discouraged and less proactive in pursuing new strategies immediately after 
exit as they do not wish to be associated with failure (Leonard-Barton, 1992). In such cases, managers may prefer to move on and forget the experience which may, in turn, reduce the benefits of learning from the experience leading to knowledge loss and unlearning (Mariano, Casey, and Olivera, 2018; Levitt and March, 1988). For instance, it would have become apparent to re-entrants how difficult it is to set up a subsidiary, whilst at the same time re-entering via a lower commitment mode would be perceived negatively. Contrastingly, low commitment investments, such as non-equity partnerships, are considered temporary by firms and require relatively less efforts from managers and therefore they would not be put off by the limited appreciation of their experience by the MNE.

Hence, the links between efforts invested in setting up a foreign subsidiary and the exit outcome, for both the MNE and managers involved, make depth of experience more of a deterrent to re-entry. Organizational forgetfulness often takes time (Mariano et al., 2018). It may, therefore, take time for re-entrants to forget the exit experience and the efforts put into the establishment and management of the subsidiary before they consider re-entry. Further, the costs of acquiring deeper knowledge may be irreversible in the short term due to difficulties in selling off the acquired assets or re-deploying them to other markets or activities (Belderbos and Zou, 2009; Isobe et al., 2000). Overall, the high cost of exit, associated with high commitment modes, can increase the perceived uncertainty of operating in the market, making managers extra vigilant and encouraging them to take measured steps before re-entering. Thus, we propose that:

Hypothesis 2: The depth of host market experience is negatively related to speed of re-entry.

\subsection{Nature of host market experience and speed of re-entry}

How firms codify their experiences and utilise them in decision making depends not only on the 'frequency' of past experiences (i.e. length of experience in a foreign market), but also on how closely 'related' experiences are to the new decision being made, which we refer to in this study as the nature of past experience (Levitt and March, 1988, p. 328). The nature of past experience refers to whether firms have previously abandoned the market due to poor performance for which management are to 
blame or due to changing external circumstances. The inherent relatedness of the decision to exit to the re-entry decision makes the nature of a re-entrant's experience, reflected in the exit motives, more readily pertinent to managers deciding whether or not to delay re-entry. Understanding the nature of the experience accumulated in a market is important for managers choosing to re-enter a market, because experiences accumulated when exiting that market - which often result in enduring memories and reluctance to re-experiment - are likely to be more present in organisational memory (Gong, Zhang and $\mathrm{Xia}, 2017$ ) and weigh more heavily than experiences obtained from operating in the host market over a longer period of time (Padmanabhan and Rao, 1999). In instances where losses because of exit "hurt" more than the potential "feel good" of successful re-entry (Liesch, Welch and Buckley, 2011; March, 2010), managers may become risk-averse (Gong et al., 2017; Liesch et al., 2011) and delay re-entry.

Exit due to poor performance in the host market may indicate to the management that the firm did not have the appropriate strategy or sufficient capabilities to operate effectively in the host market compared to its competitors (Benito and Welch, 1997; Benito, 2005; Mellahi, 2003). Given the nature of this past experience, the MNE would be expected to require a time-out period to re-assess previous decisions and acquire new capabilities in order to develop a new market strategy. Danone's multiple exits from China's dairy and confectionary markets were followed by a rebranding and customisation of the product offering, and more appropriate selection of local partners, which resulted in earlier reentries for the company. Relatedly MNEs may re-enter early to sustain the momentum gained prior to the negative exit experience and ensure that planned changes in re-entry strategy remain relevant to the host market conditions. When the exit is associated with managerial capabilities and decision-making processes, managers may also be subject to more scrutiny from investors and thus incentivized to unpack the causes for their failed operations and address them. Because managers do not wish to be associated with failure and blamed for market exit, they would seek to re-enter earlier. We propose that firms which have had negative experiences and have underperformed in the market, rather than admitting to a failed course of action, opt for reinforcing their market commitment through early reentry, in order to increase their gains, prove that the initial decision to enter was not a mistake and to illustrate that the firm was not weakened by this decision. 
In turn, companies may be pushed out of the market irrespective of their performance because of changing circumstances in their external environment that are beyond their control, such as regulations against foreign investment in some sectors, or local stakeholders' hostility, such as boycott towards certain industries or firms (Hoskisson, Wright, Filatotchev and Peng, 2013). The nature of such experiences is likely to lead to delayed re-entries. When the Chinese console market regulated electronic games content in 2000, Nintendo and Sony (Japan) felt unwelcome to sell their consoles in China, exited and re-entered 14 years later. Involuntary exit experiences can represent a source of re-entry deterrence in the short term as managers become more focused on protecting what they have gained whilst operating in the market the first time around, rather than risking early re-entry. This experience is not expected to trigger a re-assessment of managerial judgement. Hence, we propose the following:

Hypothesis 3: The nature of experience influences speed of re-entry such that, exit due to poor performance is positively related to speed of re-entry compared to involuntary market exit.

\subsection{Host institutional quality and speed of re-entry}

The choice of when to re-enter may depend on how managers perceive the host institutional environment related to aspects such as resource acquisition, setting up operations in the market, accessing market intermediaries, and (re)attaining market legitimacy (Surdu et al., 2018b). The challenge, however, is when the institutional environment is ambiguous (Townsend and Hart, 2008) and characterised by conflicting and poorly enforced rules and regulations that may, in addition, be constantly changing as the institutionalisation processes unfolding during the time-out period are not necessarily predictable (Kostova, Roth and Dacin, 2008). The ambiguity inherent in an economy with poor quality institutions can only be reduced over time (Tan et al., 2007). When the institutions and policies of host countries are not consistent with the cornerstone of institutional quality, namely economic freedom (Gwartney and Lawson, 2003; Khanna, Palepu and Sinha, 2005), reluctance associated with investing in a market may occur. This is because economic freedom - "the degree to which a market economy is in place, where the central components are voluntary exchange, free competition and protection of persons and property" (Berggren, 2003, p. 193) - determines whether 
institutions function correctly and consistently, and whether they contribute to increased market efficiencies or whether they hamper the procurement of firm resources (Tan et al., 2007). In environments with weak institutional quality, the lack of transparency associated with not having accurate information about "accepted practices related to capital markets, including the legal and judicial system, the government's macroeconomic and fiscal policies, accounting norms and practices (including corporate governance and the release of information), ethics, corruption, and regulations, customs and habits compatible with the norms of society" (Millar, Eldomiaty, Choi and Hilton, 2005, p. 163) will lead managers to perceive the host environment as ambiguous. When institutional quality is weak, re-entering too early can increase the possibility of MNEs choosing inopportune strategies, as not sufficient time has been allocated to learning about the market.

Whilst slowly shifting towards market based economies, countries with weak quality/ambiguous institutions remain heavily regulated with low macroeconomic stability and reduced economic freedom. This may influence the time it takes to (re-)enter as local institutional actors may set restrictions on the amount of ownership a firm can take in a market (Hsu et al., 2017; Putzhammer, Fainshmidt, Puck and Slangen, 2018; Tan et al., 2007). Hostility to foreign firms characterized the French automotive industry in the 1960s and 1970s. In response to government imposed tariff levels up to $220 \%$, Ford Motor (U.S.) established production facilities in France, which they closed down in the mid-1960s due to over-involvement of government in the company's operations. Chrysler and General Motors' (U.S.) attempts to integrate their French and European operations were also obstructed by successive changes in legislation and by government instability, which encouraged national autonomy and supported unproductive national players at the expense of market efficiency. Foreign automakers waited 15 years to renegotiate their re-entries into France. Because re-entry uncertainty is already high, MNEs may trade-off early re-entries to ensure that they manage with the institutional ambiguity caused by incorrect and inconsistent application of laws and legislations in the host market.

Operating effectively in markets characterized by weak institutional quality requires the MNE to possess market and non-market capabilities to deal with institutional ambiguities and avoid miscalculating investment opportunities (Delios and Henisz, 2003; Liou, Chao and Yang, 2016; Meyer et al., 2009). Hence, more time and resources need to be spent to acquire this information and bypass 
institutional voids. Having exited South Africa due to pressures from the apartheid regime, Standard Chartered (U.S.) decided that "the time was right" to re-enter after a decade during which the company built its business elsewhere in Africa. Bypassing institutional ambiguity through obtaining institutional credibility from key actors in weaker quality host institutional contexts requires time to harvest (Miller, 1992). This is particularly the case after exiting a market and disrupting relationships with institutional actors that can provide political clout and increase bargaining power with governments.

With a greater level of institutional quality, ambiguity is reduced. Hence, the time and effort needed to acquire information about the market also becomes reduced. Foreign firms require fewer permits, formalities and licenses to operate in such markets (Doh, Rodrigues, Saka-Helmhout and Makhija, 2017). The higher the quality of institutions, the more re-entrant firms may wish to take advantage of current opportunities and not wait long to re-enter, since those markets may also appear attractive to other potential entrants and or re-entrants. Thus, we propose the following:

Hypothesis 4: A higher level of host institutional quality is positively related to speed of re-entry.

\subsection{Joint effects of type of experience and host institutional quality}

Meyer et al. (2009) and later Gaur et al. (2014) highlighted that institutions play a moderating role in the (intangible) resource considerations for entry strategies. Similarly, we propose that host institutional quality affects not only the manner in which new resources can be acquired but also how previous resources can be utilised. This is because the value of possessing prior experience accumulated in the past can be expected to increase with improvements in the quality of host institutions (see also Brouthers, Brouthers and Werner, 2008). This is realized through several mechanisms.

Intangible resources such as knowledge and experience accumulated over time are, indeed, valuable, but only if those resources can be appropriately encoded, interpreted, converted into organizational learning and subsequently fed into organizational memory and routines (Grant, 1996; Schulz, 2001). However, not all knowledge can be codified (Nonaka and Takeuchi, 1995; Saviotti, 1998) particularly if acquired in weak quality/ambiguous institutional environments. Ambiguity 
encapsulates the degree to which information and knowledge acquired through direct experiences can be absorbed and transferred (Simonin, 1999) to subsequently be exploited via early re-entry. The ambiguity inherent in unstable and weaker quality host institutional environments makes it difficult to codify, interpret, and learn from, experiences accumulated over time (Sun, Mellahi and Wright, 2009). Firms operating in such institutional contexts may rely significantly on informal institutions and personal relationships of management with local market stakeholders (Li, Zhou and Shao, 2009). This, in turn, means that the knowledge acquired through experiences is tacit and deeply rooted in the managers' involvement in a specific institutional context (Nonaka and Takeuchi, 1995). Often firms may have to rely on the know-how, technologies, resources and expertise of local stakeholders which further increases the complexity of a particular knowledge source (Simonin, 1999). This knowledge acquired through experience may not be documented within the firm through a formal, systematic language and may therefore be lost or forgotten. This also makes the knowledge acquired through experience more fragmented and more difficult to interpret and utilise in subsequent re-entry decisions.

In contrast, when a firm operates in an environment characterized by relatively higher quality institutions, knowledge and experience resources may become augmented and, all else considered, firms have no motivation to delay their re-entries. Accordingly, we hypothesize that:

Hypothesis 5: The positive effect of length of experience on speed of re-entry is stronger if the firm has experienced a host environment with a higher level of institutional quality.

Second, the quality of host institutions can moderate the negative effect of depth of experience on the speed of re-entry, i.e. by reducing it. The presumption of higher host institutional quality may reduce ambiguity because the risk of being vulnerable and possibly incurring further loss is diminished through trust in institutions that managers understand. Since trust can originate from outside relationships, on the basis of institutional quality (Noteboom, 2007), countries vary in the extent to which there are institutions that support trust. Where the quality of host institutional environments is reduced, trust can be fragile and firms may feel more vulnerable to the abuse of host institutional actors or their opportunistic behavior (Dau, 2018; Henisz and Zelner, 2005; Zeng et al., 2013). Henisz and Zelner 
(2005) highlighted that foreign investors tend to have the upper hand prior to making a significant investment in countries characterized by low quality institutions, where local firms need access to scarce capital and new technologies, but this influence is reduced when capital is invested in a market and the expertise is already diffused. In contrast to simple market transactions, significant investments are based at least to some extent on interacting, and sharing knowledge and prior experiences, with local stakeholders such as partners, suppliers, distributors, regulators and so on. When managers trust in relationships established with local actors, institutions are perceived as more credible and the negative effects associated with for instance, divesting a wholly owned subsidiary, may become reduced. We argue that trust in institutions may lead firms which have previously been more deeply involved in the host market not to delay their re-entries when host institutional quality is high.

Hypothesis 6: The negative effect of depth of experience on speed of re-entry is weaker if the firm has experienced a host environment with a higher level of institutional quality.

Third and relatedly, the lack of trust arising from the absence of specialised intermediaries, regulatory systems and contract-enforcing mechanisms may hamper the implementation of new, potentially improved strategies (Khanna et al., 2005). When host environments are characterized by weaker quality/ambiguous institutions, firms require more time to identify the root cause of their mistakes and devise better re-entry strategies. For instance, if re-entrants cannot find skilled market intermediaries to inform them about customer demand and enable re-entrants to adapt their strategies, then those reentrants may take longer to revisit their strategies which will delay re-entry. Galleries Lafayette (France) re-entered China in 2013, after having exited in the late 1990s due to poor demand for their products. The company had difficulties differentiating themselves in the market from competitors and faced challenges to obtaining information regarding the factors determining their customers' increased willingness to pay for fashion items. Consequently, the company waited to find an experienced and reliable joint venture partner who helped them learn about the market and refocus strategic efforts on the high-end niche market segment. In contrast, firms entering high quality institutional environments 
can be expected to take for granted the important role played by institutions in the execution of their strategies (Khanna et al., 2005; Meyer et al., 2009; Surdu et al., 2018b). Thus, we hypothesize that:

Hypothesis 7: The positive effect of the nature of experience on speed of re-entry is stronger if the firm has experienced a host environment with a higher level of institutional quality.

An overview of the hypothesized relationships between experience types, host institutional quality and re-entry speed is presented in Figure I.

$$
\text { --- Insert FIGURE I about here --- }
$$

\section{Methods}

There are no established databases from which to obtain data concerning MNE market re-entry. This obliged us to collect data from reports in the global business information and research databases Factiva (owned by Dow Jones) and LexisNexis (owned by Reed Elsevier). These databases contain information on the business activities of firms as reported by over 600 continuously updated newswires. These newswires include publicly available and licensed sources, such as, but not limited to, Wall Street Journal, Reuters, The New York Times, Bloomberg, and Nikkei; research databases such as Factiva and LexisNexis are increasingly used to examine under researched MNE strategies (see Surdu et al., 2018b). Scholars also recognise the value of content analyses to extracting replicable and valid inferences from a large body of text (see Gaur and Kumar, 2018). We insured inter-coder reliability by developing a systematic, predominantly deductive coding scheme. Data collection and data coding processes are cited as the most critical steps to achieving reliability and validity in content analyses (Gaur and Kumar, 2018) and consequently, we discuss these processes in detail. 


\subsection{Data source and data collection}

Data searches in Factiva and LexisNexis can be conducted by region, subject, industry, time frame and company metadata. In this study, we decided to make no exclusions based on home country, host country, time of exit, time of re-entry, specific companies or industries, and used keyword searches instead. The next stage was therefore deciding on the key words used to identify foreign market re-entry phenomena first in Factiva and subsequently in LexisNexis for reliability checks. For this, we used Welch and Welch's (2009, p. 568) definition of re-entry as "a process involving a period of international business activity, then exit from international operations, followed by a time-out period of some duration, then a process of international re-entry, concluding with successfully renewed international operations". The list of key words we used consisted of references to a firm re-entering a foreign market after exit, namely 're-entry'/ 're-enter' / 'return to' / 'back in' / 're-internat*' AND 'market'. Our search terms are purposefully broad to ensure that we capture the phenomena studied. Following these searches, over 200,000 business news articles were accessed and downloaded into pdf format. Next, each article was scanned to eliminate those articles where the focus of the news story was not on an organization re-entering a host market, as well as duplicates given that Factiva and LexisNexis collected data from similar sources. A total of 2810 articles corresponding to 1377 re-entry events were identified.

We note that although the definition of foreign market re-entry as provided by Welch and Welch (2009) is straightforward, we provide some further clarifications in order to enable replication of this study. (1) There are dissimilar views on what constitutes foreign market exit or withdrawal. Some evidence indicates that firms go through periods of increasing and decreasing their international commitment in a market (Vissak and Francioni, 2013). To create a data set for analysis, only cases of total market exit were included in the sample, which led to the elimination of 40 articles. This decision is in accord with scholars who maintain that the reasons for reducing and subsequently enhancing international operations should be studied separately (Surdu et al., 2018b). (2) The definition of foreign market re-entry refers to the firm level of analysis, in that it considers companies that have exited foreign operations whilst maintaining a domestic presence prior to re-entry. Although entrepreneurs - who may sell a company and re-enter with a different firm - may be an interesting group of re-entrants, this phenomenon is beyond the scope of this study and led to the elimination of 22 articles. (3) This data 
sample does not include firms which exited one foreign market and subsequently entered a different market because this activity is analytically different from the focus of this study; as a result, 19 articles were eliminated. (4) Following the initial identification of re-entry, further searches in the databases are necessary to confirm that a given firm had, in fact, re-entered a previously exited market. Consequently, 57 articles were eliminated because data concerning re-entry was speculative. (5) Project operations are a dominant mode of international expansion for some firms (e.g., in the construction sector) which regularly exit and re-enter markets because this process is an inherent part of their business model (Vissak and Francioni, 2013). Consequently, 32 articles were excluded from the database because they involved project-based businesses. (6) Another 287 articles were eliminated as they referred to domestic market exit, i.e. exit from an industry sector, followed by re-entry into that sector. (7) We only included in our sample re-entrants that had been out of the market for at least one year in order to avoid cases of partial market exit. This led to 25 articles being eliminated. The observation period starts in 1980 and ends in 2016 and includes a total of 2328 news articles corresponding to 1020 events, that is, all reentry events which have been identified in the databases and are in line with the scope of the study. Key characteristics of the sample are provided in Table I.

\section{--- Insert TABLE I about here ---}

\subsection{Data coding}

Our coding scheme is theory driven (Gaur and Kumar, 2018), which is reflected in the deductive approach to content analysis undertaken in this study, whereby we use the antecedents and strategies examined with initial market entry and exit to inform a body of knowledge on re-entry. Yet, new codes also emerged following our pilot test of 100 re-entrants.

We started the coding process with the following codes to analyse the data collected from the business news reports: (1) name of the firm; (2) industry; (3) home country; (4) host country; (5) year of initial entry; (6) year of exit ${ }^{1}$; (7) year of re-entry ${ }^{2}$; (8) mode of operation; and (9) motives for the exit. Events of foreign market re-entry were compiled from interviews with key managers, CEOs and industry analysts conducted by journalists around the time of market exit and around the time of re-

\footnotetext{
${ }^{1}(6),(5)$ We used this data to calculate our "EXPERIENCE_LENGTH" variable.

2 (7), (6) We used this data to calculate the "speed of re-entry".
} 
entry. These reports tended to contain data regarding the specific years in which the firm initially entered, exited and re-entered the market, as well as qualitative information, such as the motivations of a firm to exit the host market and the mode in which the firm was operating in the market during the initial entry. We used previous classifications to distinguish between operation modes and we made no exclusions to the operation modes selected, namely: (i) exports; (ii) non-equity alliances (franchising, licensing); (iii) joint ventures; and (iv) wholly owned subsidiaries. To codify the motives for exit, we also used widely accepted classifications of exit motives (Benito and Welch, 1997; Benito, 2005; Mellahi, 2003). Previous classifications of market exit agree that exit can be seen as (i) voluntary, i.e. the firm chooses to abandon the market itself and (ii) involuntary, i.e. the firm is pressured by local governments to exit. Each author used these codes in the pilot test.

During the pilot test, some new insights emerged which were later incorporated in the final coding frame. Specifically, all four authors found that firms often list two or more factors associated with having exited the market which requires further unpacking of these categories of factors. Within the category of (i) voluntary exits, exit due to poor market performance is referred to as (a) lack of understanding of consumer needs resulting in misfit of product to market; (b) inappropriate pricing strategies; (c) competition leading to loss of market share. Further, three of the four authors discovered that managers made a distinction between exit due to poor market performance and exit due to poor performance with the operation mode. Hence, we include these sub-categories of voluntary exit in the final coding framework. All four coders highlighted that amongst multi-business firms, some would exit a sector in the host market, whereas they remained to operate there in another sector, hence, we added a new code to capture the potential effect of being present in the market. As discussed in the following sections, the content analysis from Factiva/LexisNexis was supplemented with information collected about firm characteristics, e.g. size, age, general internationalisation experience, (Annual reports/Company history) and host institutional quality (Economic Freedom of the World Index).

\subsection{Variables}




\subsubsection{Dependent variable}

Our dependent variable is the speed of re-entry measured as the period of time between two wellobserved events namely the event of exit and the event of re-entry. Previously, this has been referred to as the time-out period (Welch and Welch, 2009; Surdu et al., 2018b).

\subsubsection{Independent variables}

Our operationalisation of experience effects is premised on the perspective that host market specific knowledge is obtained through experience of operating in the previously exited market. EXPERIENCE_LENGTH is measured as the number of years the firm operated in the host market between initial entry and exit. As in previous studies (Barkema and Vermeulen, 1998; Eriksson and Chetty, 2003; García-García et al., 2017), EXPERIENCE_DEPTH is a measure of knowledge acquired through commitment in a foreign market and reflected in the mode of operation in that market, hence, operation mode was coded in the database into four dummy variables namely: EXPORTS, NONEQ_ALLIANCES, JV and WOS. Each variable representing a mode of operation takes turns as an independent variable in the regression to allow for comparisons. EXPERIENCE_NATURE reflects the motives for the exit. After using Factiva and LexisNexis to identify why re-entrants had exited the market based on previous classifications of exit, three dummy variables were created, namely: poor market performance (POORMKT_PERFORMANCE), poor performance with the initial mode of operation (POORMODE_PERFORMANCE) and involuntary exit (INVOLUNTARY_EXIT). We found that the factors associated by re-entrants with poor market performance (i.e. lack of understanding of consumer needs resulting in misfit of product to market, inappropriate pricing strategies and competition leading to loss of market share) were highly correlated, since misunderstanding of customer tastes may lead to unsatisfactory market performance, whereas local competitors tend to have locally adapted products and services. The study tested for the effect on re-entry speed of firms exiting voluntarily compared to being forced out of the market (as a re-entrant cannot simultaneously exit voluntarily and involuntarily). ${ }^{3}$

\footnotetext{
${ }^{3}$ For robustness checks we added each exit motivation to the model separately. This did not change the effect of the relationships between exit and re-entry commitment strategies.
} 
Host institutional quality is measured using data from the Economic Freedom of the World Index, which is viewed as a quality measure of a country's institutional and policy environments (Meyer et al., 2009). The composite index is based on five main areas: 1) size of government, 2) legal system and intellectual property rights (IPR), 3) sound money, 4) freedom to trade internationally, and 5) regulation. Countries are ranked across a spectrum from most free (minimal state intervention $=$ ' 10 ') to least free (dominant state intervention $={ }^{\prime} 0$ '). Host institutional quality is measured at time $t-1$, with a one-year lag prior to exit. Given that previous research found high correlations between institutional scores (Meyer et al., 2009; Xia et al., 2009), factor analysis resulted in two measures of institutional quality being used. Legal system and intellectual property rights, sound money, freedom to trade internationally and regulation loaded onto one factor - HOST_QUAL (1) and size of government loaded onto another factor - HOST_QUAL (2). HOST_QUAL (2) reflects whether the country relies on personal choice and markets rather than government budgets and political choices. This means that high income countries may score high for the other factors and low for size of the government whilst the opposite is valid for low income countries. ${ }^{4}$

\subsubsection{Control variables}

Firm size (LNSIZE) is measured as total number of assets (Delios and Henisz, 2003), with a logarithm transformation at t-1 exit. Firm age (AGE) is measured as the number of years (Zhou and Wu, 2014) from foundation until t-1 exit. We also controlled for other experience related factors (Luo and Peng, 1999; Brouthers et al., 2008). The total number of international countries entered since inception was measured (NCOUNTRY_INT) as was the total number of international countries within the host region entered since inception (NCOUNTRY_HOST), both calculated at t-1 exit. General experience intensity (total number of years of internationalisation, NYEARS_INT) and host experience intensity (total number of years in the host region, NYEARS_HOST) were also calculated at t-1 exit. Similar to

\footnotetext{
${ }^{4}$ We compiled data to measure institutional quality from other databases such as the World Bank that have been used in previous research (e.g. Meyer et al., 2009; Xia et al., 2009) and did not find significant differences; e.g. 'freedom to trade internationally' is correlated with 'regulatory quality' $(\mathrm{r}=0.71)$ and 'property rights' $(\mathrm{r}=0.75)$. Gwartney and Lawson (2003) also noted that, when the components of the index are highly correlated (ranging from 0.59 to 0.93 ) the ratings and rankings of institutional quality are not very sensitive to variations in the weights assigned to the components, the exception being 'size of government' which we also treat as a separate variable.
} 
previous studies, factor analysis confirmed that the two measures of experience intensity loaded onto a single factor (NYEARS, Cronbach's alpha $=.82$ ) (see also Brouthers et al., 2008). The variable capturing whether the re-entrant was already present in the market is PRIOR_PRESENCE; the variable takes the value of "1" if following the exit event, a re-entrant continued to operate in the host market through a different division or in a different market sector, and "0" otherwise. Further, we controlled for whether re-entrants tend to feel more confident in the usefulness of knowledge possessed and reenter faster into countries within their home region (Surdu et al., 2018b); the variable REG takes the value of ' 1 ' when the home and host countries are within the same region (regionalisation patterns are between countries within the European Union, North America, Latin America, Asia, Australia and New Zealand and Africa). Finally, we have four industry dummies representing the top industries in our sample: AUTOMOTIVE, RETAIL, FINANCIAL SERVICES and CONSUMER ELECTRONICS.

The standard deviations and pairwise correlations for all the variables are reported in Table II. The VIFs range between 1.08 and 3.24, suggesting no serious problems of multicollinearity for the analysis.

\section{--- Insert TABLE II about here ---}

\subsection{Modelling procedure: Cox proportional hazards model}

Our hypotheses are tested using the Proportional Hazards Model analysis developed by Cox (1972). Cox's proportional hazards model is amongst the most commonly used regression analysis models to investigate what is generally referred to as survival data. Based on the hazard function, the rate of occurrence of the re-entry event at duration $t$ equals the density of events at $t$ divided by the probability of the focal event occurring at a pre-determined point in time, i.e. firms re-entering the market within two years (five years) (ten years) after exiting that market. In a proportional hazards model, the unique effect of a unit increase in a covariate is multiplicative with regards to the hazard rate that the event has occurred at a time $t$. For instance, having greater length of experience may mean that the firm does not have to wait more than one or two years to re-enter in the same way in which divesting a wholly owned subsidiary may translate into firms re-entering ten years after exiting, a period of time that may be necessary for them to recoup their losses before re-entering. Covariates can be both continuous (length 
of experience, host institutional quality) or binary (depth of experience, nature of experience). In the case of a continuous variable, the exact effect of the covariate depends on the baseline hazard function. Fuentelsaz et al. (2002: 252) explained in more detail that the main assumption of the hazards model is that 'the hazard functions of all individuals are a multiple of an unspecified baseline hazard function. Therefore, the baseline hazard function is an arbitrary and non-negative function in time'. In this study - much like in all additive models - we expect that the effect of the covariates is the same at all times $t$, with each unit increase in the covariate resulting in proportional scaling of the hazard.

We also recognise that the proportional hazards model has seen a number of extensions since the original Cox design (1972). Notable amongst those extensions is the idea of considering specific time scales or intervals in which certain events have occurred (Andersen and Gill, 1982). The majority of previous studies on the timing/speed of initial market entry tend to examine the order of entry into foreign markets by considering whether firms define themselves as 'first movers', 'early followers' or 'late followers' (c.f. Isobe et al., 2000). Given the potential biases arising from this method, scholars have recommended the use of actual time periods of entry (see Gaba et al., 2002, p. 41). The time-out period between exit and subsequent re-entry varies between one year and 20 years, thus allowing us to investigate the covariates associated with entry at different points in time. We used the SPSS statistical package to divide the speed of re-entry into four equal quartiles: "one to two years", "three to five years", "six to ten years" and "eleven to twenty years". In this way, we are able to provide a more nuanced explanation concerning what drives the speed of re-entry at different intervals of time and whether the factors determining re-entry within one or two years of exit have the same level of significance with the factors determining later re-entry, for instance, waiting more than 10 years prior to re-entering. Speed of re-entry was computed into three dichotomous variables, whereby in each observation the censored subject is taken into account as one whose event is ' 0 '. We measured whether the firm re-entered within two years or waited longer $(1 ; 0)$; within five years or longer $(1 ; 0)$ and within ten years or longer $(1 ; 0)$. Given this established method of coding the data, each time-frame is compared to the remainder of the sample.

Survival models were developed for use with continuous data, however, such data is generally not available in studies of international business, which includes studies on the speed of foreign market 
entry decisions (Fuentelsaz et al., 2002; Isobe et al., 2000). In this study, we have annual observations regarding the external, host market-related covariates by examining their value at the time of exit, because we assume that the assessment of risk and costs that managers make at the time of exit will influence how early they re-enter. Further, since we grouped the speed of re-entry as intervals, the model is time-dependent but remains fixed within specific time intervals as estimation takes place through the maximum likelihood technique (Blossfeld and Rohwer, 1995).

\section{Results}

In all tables, Model 1 presents the baseline estimation which includes the controls. The effects of experience are tested in Models 2-4. The individual effect of host institutional quality is subsequently added in Model 5. The effects of the interactions between experience and institutional quality are presented in Models 6-8. The estimated coefficients shown in Tables III-V should be interpreted as representing the increase (or decrease) in the expected log of the instantaneous re-entry rate with each additional unit of the covariate, e.g. a positive coefficient in Table III signifies an increase in the entry rate in the first two years of market exit which translates into a very early re-entry, whilst the converse is true for negative coefficients. The differences in the effects of experience and host institutional quality at different points in time confirmed our decision to unpack what constitutes early versus late re-entry.

With regard to the control variables: A large firm size is associated with foreign entrants possessing comparatively more financial and other resources that enable them to make riskier (re-)entry decisions (Gao and Pan, 2010; Fuentelsaz et al., 2002). Generally, our results show that SIZE has a negative effect on the speed or re-entry. This may be because larger firms remain focused on international growth by entering other foreign markets and may be less dependent on a small number of markets, thus postponing the re-entry decision into a market that may be viewed as more uncertain. Results suggest that older firms (AGE) re-enter within ten years after exit compared to waiting longer. Firms with prior presence in the market (PRIOR_PRESENCE) also re-enter relatively early, within five and ten years, but the effect is reduced when adding the covariates. Firms which have been international for a greater number of years (NYEARS) tend to re-enter after ten years. We also found evidence that 
firms operating in the consumer electronics industry tend to re-enter within ten years, but not necessarily earlier. We found no evidence to suggest that firms overestimate the similarities between the home and host countries (Fuentelsaz et al., 2002) by re-entering earlier into neighbouring countries.

Our main findings are as follows: Contrary to findings in previous studies on initial entry (Casillas and Moreno-Menendez, 2014; Delios and Henisz, 2003; Gao and Pan, 2010) and contrary to our prediction in H1, EXPERIENCE_LENGTH does not have a positive effect on the speed of $r e$-entry. In fact, the length of experience accumulated in the market between initial entry and exit delayed reentry, meaning that firms with more experience accumulated over time wait more than ten years to reenter. We argue that the length of experience alone may not be a key determent for early re-entry because some experiences may be too ambiguous to interpret (March, 2010) and learn from.

We found that other types of experiences have differing effects on re-entry speed. Firms which were previously operating via non-equity modes such as EXPORTS $(\beta=-0.404, p$-value $<0.01)$ and NONEQ_ALLIANCES $(\beta=-0.443, p$-value $<0.01)$ and firms which operated though WOSs $(\beta=-$ $0.614, p$-value $<0.001$ ) had a greater hazard to delay re-entry compared to JVs; these effects are most significant within five and ten years after exit (see for instance, Model 3 in Table IV). This means that JVs are more flexible not only compared to WOSs but also when compared to non-equity operation modes. Perhaps MNEs which operated via non-equity modes have not acquired the necessary knowhow to operate in the market and or attracted a large enough customer base and choose to re-enter when the market is more favourable and when there is demand for their products. What we also found is that the explanatory power of all three models significantly increases when EXPERIENCE_DEPTH is considered indicating that studies on speed of re-entry should examine depth of experience effects 5 .

Further, as suggested in H3, the coefficients for exit due to poor market (mode) performance have a strong positive effect on re-entry speed, decreasing the hazard of late re-entry in all three regression models. An explanation for the effects of POORMKT_PERFORMANCE in particular is that for firms which exited due to an increase in operation costs, competition or a misfit of product strategies, re-entry may involve changes in product, positioning, distribution and or pricing strategies. Such

\footnotetext{
${ }^{5}$ It should be noted here that EXPORTS and NONEQ_ALLIANCES were also compared to WOS but given the non-significant results in all of the regression models, the results are not reported in the final models.
} 
changes should be implemented when the experience is relatively fresh in the minds of the decision makers whereas the exact time it takes to make such changes may vary between re-entrants. Notable amongst the results concerning experience nature is also that the expected change in the log of re-entry rate is highest for POORMODE_PERFORMANCE for re-entry within two years, i.e. $\beta=1.158, p$ value $<0.001$ (Model 4 in Table III). Firms which have identified the mode of operation as the main cause behind their poor performance in the host market are, as hypothesized, incentivized to repair their mistakes, perhaps by even re-entering via a different mode (Surdu et al., 2018b).

The covariates measuring host institutional quality showed positive and highly significant coefficients, generally indicating, as proposed in $\mathrm{H} 4$, that high quality host institutional contexts reduce the uncertainty associated with delayed re-entries. The positive effect of INST_QUAL (1) is largest for firms re-entering within five years after exit $(\beta=0.332 ; p$-value $<0.001$; Model 5 in Table IV) whereas the effect of INST_QUAL (2) is largest for re-entry within ten years $(\beta=0.142 ; p$-value $<0.001$; Model 5 in Table V). Within two and five years of exiting, weaknesses in other areas such as property rights, trade openness and sensible regulation are more immediately important, whilst aspects such as the size of government take longer to change and become more relevant in later stages following exit.

--- Insert TABLES III-V here ---

Next, we proposed that quality of institutions enhances the positive effects of prior experiences and reduce their negative effects. In $\mathrm{H} 5$ we predicted that, when a firm operates in an environment characterized by relatively higher quality institutions, knowledge and experience resources may become augmented. H5 is supported in that the interaction coefficients for INST_QUAL and EXPERIENCE LENGTH were positive in all models, although significant only for re-entry within five and ten years. This is aligned with our earlier findings that host institutional quality plays a lesser role in the early period after exit where experience is fresh in the minds of decision makers, whereas in later years, organizational forgetfulness together with difficulties in deciphering knowledge may increase the value of having operated in high quality institutional contexts. 
In conditions of higher host institutional quality, the negative effect of EXPERIENCE_DEPTH on re-entry speed becomes mostly insignificant (H6); in particular results suggesting that knowledge acquired through WOSs tends to delay re-entry became insignificant. To elaborate on these findings, we represent graphically the interaction effects between host institutional quality and experience depth (Figure II). We defined institutional quality as low for values below the mean and high for values above the mean (see also Meschi, Ricard and Moore, 2017). We can draw several observations from Figure II. For instance, low levels of depth of experience acquired through exports and greater depth of experience such as that acquired through JVs and WOSs can be seen to increase the probability of early re-entry when host institutional quality is high and, conversely, decrease the probability of early reentry when host institutional quality is low. In turn, there is no clear variation in the effect of lower experience depth (acquired through non-equity alliances) at high and low levels of institutional quality. Figure II indicates that firms with the highest probability of early re-entry are those which were previously operating through joint ventures in high quality (low ambiguity) host environments.

\section{--- Insert Figure II here ---}

Finally, contrary to what we proposed in H7, we found that the nature of the experience, derived from the motives for exit is linked to earlier re-entries irrespective of other factors such as the host institutional environment, which confirms the important role of related experiences, such as the exit experience in shaping considerations for re-entry timing strategies.

\subsection{Supplementary analysis and robustness checks}

Our first robustness test considers the possibility that events occurring in the host market may drive the decision of when to exit the market, thus also influencing the time it takes for the firm to re-enter. We tested different year dummies to control for any variation that may result from the $2008(2007,2008$, 2009) recession in Western countries and the 1997 (1996, 1997, 1998) financial crisis in Asian countries, i.e. whether there was a concentration of market exit events around those periods which may prompt re-entries merely as a result of increased stability in the economic system. These robustness checks did not result in any observable changes for the results of our regression models. 
Our second robustness test evaluates the possibility that firms decide to reduce the time-out period in markets that are perceived as more attractive (Hsieh and Vermeulen, 2014). This may be the case with entering markets characterized by more uncertainty as well as high attractiveness due to their potential for future growth such as India, China, and more recently Russia and Brazil. The effect of host market size is measured as GDP per capita, based on purchasing power parity (PPP) to allow for a comparison of values over time and locations (World Bank indicators) and host market attractiveness, i.e. net inflows of FDI to the host market (World Bank indicators). Adding host market attractiveness did not lead to any change in the values of our parameters, however, the variable host market size incurs a high degree of multicollinearity with the institutional variable represented by covariate INST_QUAL (1). The correlation between host market size and host institutional quality can produce a misleading result since we have examples of markets such as China, India and other developing nations, which although considered institutionally underdeveloped and characterized by low economic freedom, are at the same time characterized by high growth rates and demand potential.

Our third robustness test considers the possibility that re-entries into a particular country may be consolidated into a short period of time, resulting from either a political decision to open for investment or other host market related factors we may have missed in our analysis. We evaluated our data according to the host region that firms re-entered (given that there are 101 host countries in total, it would have been less useful to stratify the data per country). We found that the time firms took to reenter in each host region had a range between 1 to 20 years, with mean values between 5-7 years and similar standard deviation values amongst the regions (between 4.64 and 6.15). There is no evidence that the effects of the covariates on speed of re-entry were biased by the host location.

Finally, we tested the robustness of our Cox hazard model results using the discriminant analysis procedure. The results of the two estimation procedures are similar with regards to the independent variables that significantly discriminate between the groups. For instance, for the variable EXPERIENCE_LENGTH, we can observe that firms which have not re-entered within ten years tend to have a higher mean. In turn, the mean for POORMODE_PERFORMANCE is significantly higher for earlier re-entries in all three contexts, with the difference decreasing over time. Similarly, for institutional quality, where the differences increase over time. The potential of the covariates to 
contribute to the model varies according to the time frame studied. For instance, the covariates with greater discriminating ability when measuring re-entry within two years compared to later re-entrants are POORMODE_PERFORMANCE (0.760), INST_QUAL (1) (0.486), JV (0.331) and EXPERIENCE_LENGTH (-0.320). The covariates that best discriminate between firms engaging in re-entry within ten years compared to later re-entrants are INST_QUAL (1) (0.745), INST_QUAL (2) $(0.498)$ and WOS (-0.315). The results are aligned with our interpretation of the Cox model.

\section{Discussion and conclusions}

\subsection{Contributions to theory}

We proposed that: (1) length and nature of experience can have an uncertainty reducing effect, whilst depth of experience can have an uncertainty-enhancing effect on speed of re-entry thereby delaying reentry; and that (2) a higher level of institutional quality translating into reduced institutional ambiguity strengthens the positive effects of prior experience and weaken their negative effects on re-entry speed.

This study contributes to the organizational learning and institutional theories in three ways. First, our results show that learning from length of experience accumulated in the market, commonly referred to as experience-based learning, does not have a positive effect on the speed of re-entry as previously suggested for de novo entries (e.g. Fuentelsaz et al., 2002; Gaba et al., 2002; Isobe et al., 2000; Johanson and Vahlne, 1977). More so, experienced re-entrants tend to be late re-entrants. Firms may need time to distill the lessons learned from previously operating in the host market, particularly as they simultaneously manage the potentially traumatic and costly market exit experience. Extant literature has not considered that experience takes time to become part of organizational learning and, as such, not all experiences may become embedded in organizational routines and positively influence organizational behavior in the short term. Noting that experiences do not take place in a context-freevacuum (Gaur et al., 2014; Teagarden, Von Glinow and Mellahi, 2018), firms may indirectly benefit from the quality of institutions because superior institutions provide a platform to learn from, and utilise past experiences. We show that experience may be more useful when MNEs encounter low levels of 
ambiguity that disrupt the learning process, as in this case past experience may be more easily translated into organisational behaviors and routines (Anand, Mulotte and Ren, 2014).

We strongly argue that learning should be investigated not only as a linear, sequential process, whereby the firm accumulates experience which is translated into increased confidence in the capability to invest in an international market. Rather, experience accumulated over time may be set aside, disregarded and even forgotten (Argote and Miron-Spektor, 2011). It may be that the development of new learning that is required to make post-entry decisions occurs best under conditions where there are fewer routines to unlearn (Argote and Miron-Spektor, 2011; Tsang and Zahra, 2008).

Second, the present study provides a finely grained analysis of the impact of different types of experiences on the effectiveness of learning. We show that firms with little depth of experience and firms with significant depth of experience tend to be later re-entrants. Firms previously operating through modes such as exports, franchising or licensing, potentially lack the depth of knowledge necessary to re-enter the market relatively early nor have they necessarily planned a late re-entry. Since these firms are non-equity investors, institutional incentives do not necessarily represent a point of attraction for them. There may be fewer incentives to quickly recover the losses incurred upon exit which, in the case of firms operating via non-equity modes, would be reduced.

In turn, sharing equity and ownership with a partner may have reduced the costs of attaining deeper market knowledge (Gaba et al., 2002), whilst at the same time equipping the firm with a sufficient understanding of the market for the firm subsequently either to choose to terminate the investment, or to further invest in the market for greater control of its operations. Previous explanations for this have been that firms operating through joint ventures may find it easier to discover the gap that exists between extant and new knowledge and act towards reducing this gap and deepening their knowledge through early re-entry (see for instance, Delios and Beamish, 2004). Our findings reveal that overall, firms with the highest probability of early re-entry are those which were previously operating through joint ventures in high quality/low ambiguity host environments.

Further to this point, by considering the nature of the firm's prior experiences, our overall contention is that managers rely more on paradigms of interpretation of their negative experiences or market failures, particularly soon after having undergone those experiences. For re-entrants, poor 
performance in the host market prior to exit appears to be an incentive to reinforce management commitment to the market through early re-entry. Furthermore, whilst we did not develop unique hypotheses about mediating effects, the results suggest that, when firms' experience was acquired via joint venture collaborations which subsequently underperformed in the market, the benefits of experience and flexibility acquired through partnerships tend to be reduced in the short term, leading to delayed decision making. Firms which have had experiences with failed joint venture partnerships may need to make inferences from the lessons learned after renouncing those partnerships and alter their investment strategies. Consequently, firms may make the wrong inferences from past experiences not only in the context of experiences associated with M\&A failures (Zeng et al., 2013) but also when acquiring experiences such as operating via joint ventures. This, in turn, delays re-entry.

Third, our findings confirm that MNEs evaluate the quality of host institutions and that highquality conditions are generally associated with less risk avoidance (Xia et al., 2009), and thus earlier re-entries. Over time, firms may forget or renounce their prior experiences in the market, or the organizational decision makers associated with those experiences may have left, making external, institutional cues very important in strategic decision making. Institutional quality also reduces the negative effect of experience accumulated over time confirming our proposition that the experience acquired in higher quality host institutional contexts is less ambiguous and therefore it becomes easier and faster for firms to codify, and make inferences from, past experiences. This makes the locational features of host markets also very important for firms considering international expansion and shows the need to contextualise the effects of experience and learning in international business strategies.

\subsection{Contributions to practice}

There may be significant hurdles to being late to the market, particularly if competitors have already established operations in those markets (as suggested by the example of Marks and Spencer who waited over ten years to re-enter various European markers and are yet to achieve success internationally). Organizational forgetfulness may occur when firms have spent a long time out of the market, in which 
case there may be significant consequences of not having learned, or not being able to transform prior knowledge and experience into organizational learning and routines, and subsequently leverage the lessons learned from a failed experience when making subsequent market (re-)entry decisions. Firms either react and interpret market exit by changing their strategies and adapting to the market to avoid underperforming, or perhaps simply re-enter the market due to the limited options these firms have to grow through internationalization. In the latter case, re-entry would occur without the re-entrant firm having learned significantly. The locational features of (re-)entered markets are especially important for firms considering (re-)entry, with external cues being particularly relevant to those which wait longer before (re-)entering and for whom past knowledge may be less relevant to draw upon.

Whilst joint equity re-entries increase the likelihood of early re-entries, wholly owned subsidiaries tend to be relatively harder to implement and costlier to dissolve. Particularly if the MNE is then also to renew its market commitment through wholly owned subsidiaries (Putzhammer et al., 2018; Surdu et al., 2018b), it may take significantly longer to set up greenfield ventures upon re-entry. Where acquisitions are concerned, they may foster earlier entries but they can be costlier and contingent on the availability of appropriate targets. Timing decisions are, to some degree, inter-linked with entry mode commitment choices (Gaba et al., 2002; Isobe et al., 2000) as we identified a trade-off between early (re-)entries and degree of commitment. Whilst it is proposed that the highest performers in foreign markets are MNEs that both (re-)enter early and through high resource commitment modes (Isobe et al., 2000), managers may need to consider the trade-off between investing significantly in a market and the speed of that investment particularly given the already high risks associated with an exited market.

We point to the relevance of understanding the hurdles of being late to the market. For example, Peugeot Citroën's plans to re-enter the U.S. market came at a time when no French car manufacturers had been able to penetrate the market since the 1990s and is posited to be part of the company's financial and strategic restructuring. This case illustrates the liability of being late to the market when all other automotive companies have established dealerships in the U.S. or even manufacturing subsidiaries. Partnerships have not worked in the U.S. market for companies such as Groupe Renault (France), which places further constraints on the usefulness of past experience as a long time has passed since their exit (the 1970s for Citroën and 1990s for Peugeot) and unsurprisingly, no dealerships of Citroën or Peugeot 
still exist in the U.S. for them to acquire market knowledge from. Such examples further emphasise the importance of not waiting too long before re-entering a previously exited market.

\subsection{Limitations and future research}

We do not have information on how much of a firm's past experience is transferable, what has been forgotten or disregarded, or whether firms rely on new knowledge to become early re-entrants. Further qualitative data is required to understand how managers recall the exit experience and how much of that experience is embedded within the organization, lies with the individual decision makers involved (Zucchella, Palamara and Denicolai, 2007), or is lost when key decision makers are replaced following the exit. Smaller firms, international new ventures and or family firms (which are potentially newer to foreign entry and implicitly re-entry) may vary more in their experience resources. These firms differ from the typical large and hierarchical MNEs with regards to how and where learning is stored within the organization and how it becomes transformed into organizational routines. The knowledge and experience accumulated by smaller multinationals is tacit and thus cannot be explicitly codified (Nonaka and Takeuchi, 1995) in which case it becomes embedded in individual decision makers. Research that examines re-entries of smaller firms may explain whether experience accumulated over time may result in learning that can be exploited in the short term by re-entrants.

A fruitful avenue for future research would be to examine not only the characteristics of the firm's external, host environment but also the distance between the institutions and cultures of home and host markets (Bhaumik, Owolabi and Pal, 2018) as it may have an impact on how experiences are perceived. Informal ties between countries, such as those associated with cultural similarities, may also affect the ease with which the knowledge acquired through experiences can be understood and communicated. In a similar manner to institutions, historical ties provide incentives for economic exchanges as they increase receptivity to investment from the perspective of local stakeholders and lower perceived costs and psychological barriers of investors.

In conclusion, our findings provoke a renewal and revision of the bounded organisational learning theories as we posit that learning does not take place in a vacuum, isolated from any external 
influences. Organisational learning is a dynamic and contingent process, one highly dependent on the characteristics of the MNE's experiences and on the quality of its institutional context. Our hope is that by introducing institutional theory to the context of organisational learning, we will inspire research which considers the many other contextual factors which may have significant implications toward the idea of developing "learning organizations", and subsequently on the strategic choices made by them. 


\section{References}

Anand, J., Mulotte, L. and Ren, C. R. (2014). 'Does experience imply learning?' Strategic Management Journal, 37, 1395-1412.

Andersen, P. K. and Gill, R. D. (1982). 'Cox's regression model for counting processes: A large sample study'. Annals of statistics, 10, 1100-1120.

Argote, L. and Miron-Spektor, E. (2011). 'Organizational learning: From experience to knowledge'. Organization Science, 22, 1123-1137.

Barkema, H. G. and Vermeulen, F. (1998). 'International expansion through start-up or acquisition: A learning perspective'. Academy of Management Journal, 41, 7-26.

Belderbos, R. and Zou, J. (2009). 'Real options and foreign affiliate divestments: A portfolio perspective'. Journal of International Business Studies, 40, 600-620.

Benito, G. and Welch, L. (1997). 'De-internationalization'. Management International Review, 37, 725.

Benito, G. R. (2005). 'Divestment and international business strategy'. Journal of Economic Geography, 5, 235-251.

Berggren, N. (2003). 'The benefits of economic freedom: A survey'. The Independent Review, 8, 193211.

Bhaumik, S. K., Owolabi, O. and Pal, S. (2018). 'Private information, institutional distance, and the failure of cross-border acquisitions: Evidence from the banking sector in Central and Eastern Europe.' Journal of World Business, 53, 504-513.

Blossfeld, H. and Rohwer, G. (1995). 'Techniques of event history modelling: New approaches to causal analysis'. Mahwah, NJ: Erlbaum.

Brouthers, K. D., Brouthers, L. E. and Werner, S. (2008). 'Resource-based advantages in an international context?' Journal of Management, 34, 189-217.

Buckley, P., Doh, J. P. and Benischke, M. H. (2017). 'Towards a renaissance in international business research? Big questions, grand challenges, and the future of IB'. Journal of International Business Studies, 1-20.

Casillas, J. C. and Moreno-Menendez, A. M. (2014). 'Speed of the internationalisation process: The role of diversity and depth in experiential learning'. Journal of International Business Studies, $\mathbf{4 5}$, $85-101$.

Cegarra-Navarro, J.-G. and Moya, B. (2005). 'Business performance management and unlearning process'. Knowledge and Process Management, 13, 161-170.

Chetty, S., Johanson, M. and Martín Martín, O. (2014). 'Speed of internationalization: Conceptualization, measurement and validation'. Journal of World Business, 49, 633-650.

Cox, D. R. (1972). 'Regression models and life tables (with discussion)'. Journal of the Royal Statistical Society, 34, 187-202. 
de Holan, M. P., Phillips, N. and Lawrence, T. B. (2004). 'Managing organizational forgetting'. MIT Sloan Management Review, 45, 45-51.

Dau, L. (2018). 'Contextualising organisational learning: The moderating effects of mode of entry and subsidiary networks on the relationship between reforms and profitability'. Journal of World Business, 53, 403-414.

Delios, A. and Henisz., W. J. (2003). 'Political hazards, experience, and sequential entry strategies: The international expansion of Japanese firms, 1980-1998'. Strategic Management Journal, 24, 1153 1164.

Delios, A. and Beamish, P. W. (2004). 'Joint venture performance revisited: Japanese foreign subsidiaries worldwide'. Management International Review, 44, 69-91.

Doh, J. P., Rodrigues, S., Saka-Helmhout, A. and Makhija, M. V. (2017). 'International business responses to institutional voids'. Journal of International Business Studies, 48, 293-307.

Eriksson, K and Chetty, S. (2003). 'The effect of experience and absorptive capacity on foreign market knowledge'. International Business Review, 12, 673-695.

Fuentelsaz, L., Gomez, J. and Polo, Y. (2002). 'Followers' entry timing: Evidence from the Spanish banking sector after deregulation'. Strategic Management Journal, 23, 245-264.

Gaba, V., Pan, Y. and Ungson, G. R. (2002). 'Timing of entry in international market: An empirical study of US Fortune 500 firms in China'. Journal of International Business Studies, 33, 39-55.

Gao, G. Y. and Pan, Y. (2010). 'The pace of MNEs' sequential entries: Cumulative entry experience and the dynamic process'. Journal of International Business Studies, 41, 1572-1580.

García-García, R., García-Canal, E. and Guillén M. F. (2017). 'Rapid internationalization and long-term performance: The knowledge link'. Journal of World Business, 52, 97-110.

Gaur, A. S., Kumar, V. and Singh, D. (2014). 'Institutions, resources, and internationalization of emerging economy firms. Journal of World Business, 49, 12-20.

Gaur, A. S. and Kumar, M. (2018). 'A systematic approach to conducting review studies: An assessment of content analysis in 25 years of IB research'. Journal of World Business, 53, 280-289.

Gong, Y., Zhang, Y. and Xia, J. (2017). 'Do firms learn more from small or big successes and failures? A test of the outcome-based feedback learning perspective'. Journal of Management.

Grant, R. M. (1996). 'Toward a knowledge-based theory of the firm'. Strategic Management Journal, $17,109-122$.

Gwartney, J. D. and Lawson, R. A. (2003). 'The concept and measurement of economic freedom'. European Journal of Political Economy, 19, 405-430.

Henisz, W. J. and Zelner, B. A. (2005). Legitimacy, interest group pressures, and change in emergent institutions: The case of foreign investors and host country governments. The Academy of Management Review, 30, 361-382. 
Hilmersson, M. and Jansson, H. (2012). 'Reducing uncertainty in the emerging market entry process: On the relationship among international experiential knowledge, institutional distance, and uncertainty. Journal of International Marketing, 20, 96-110.

Hoskisson, R. E., Wright, M., Filatotchev, I. and Peng, M. W. (2013). 'Emerging multinationals from mid-range economies: The influence of institutions and factor markets'. Journal of Management Studies, 50, 1295-1321.

Hsieh, K. and Vermeulen, F. (2014). 'The structure of competition: How competition between one's rivals influences imitative market entry'. Organization Science, 25, 299-319.

Hsu, C.-W., Chen, H. and D'Arcy, C. (2017). 'Local conditions, entry timing, and foreign subsidiary performance'. International Business Review, 26, 544-554.

Hurley, R. F. and Hult, G. T. M. (1998). 'Innovation, market orientation, and organisational learning: An integration and empirical examination'. Journal of Marketing, 62: 42-54.

Isobe, T., Makino, S. and Montgomery, D. B. (2000). 'Resource commitment, entry timing, and market performance of foreign direct investments in emerging economies: The case of Japanese international joint ventures in China'. Academy of Management Journal, 43, 468-484.

Jiang, R. J., Beamish, P. W. and Makino, S. (2014). 'Time compression diseconomies in foreign expansion'. Journal of World Business, 49, 114-121.

Johanson, J. and Vahlne, J.-E. (1977). 'The internationalization process of the firm - A model of knowledge development and increasing foreign market commitments'. Journal of International Business Studies, 8, 25-34.

Khanna, T., Palepu, K. G. and Sinha, J. (2005). 'Strategies that fit emerging markets'. Harvard Business Review, June. Aavailable at: https://hbr.org/2005/06/strategies-that-fit-emerging-markets.

Kostova, T., Roth, K. and Dacin, M. T. (2008). 'Institutional theory in the study of multinational corporations: A critique and new directions'. Academy of Management Review, 33, 994-1006.

Leonard-Barton, D. A. (1992). 'Core capability and core rigidities: A paradox in managing new product development. Strategic Management Journal, 13, 111-125.

Levitt, B. and March, J. G. (1988). 'Organizational learning'. Annual Review of Sociology, 14, 319-340.

Levchenko, A. A. (2007). 'Institutional quality and international trade'. The Review of Economic Studies, 74, 791-819.

Li, J. J., Zhou, K. Z. and Shao, A. T. (2009). 'Competitive position, managerial ties, and profitability of foreign firms in China: An interactive perspective'. Journal of International Business Studies, 40, 339-352.

Liesch, P. W., Welch, L. S. and Buckley, P. T. (2011). 'Risk and uncertainty in internationalisation and international entrepreneurship studies: Review and conceptual development. Management International Review, 51, 851-873. 
Liou, R.-S., Chao, M. C.-H. and Yang, M. (2016). 'Emerging economies and institutional quality: Assessing the diferential effects of institutional distances on ownership strategy'. Journal of World Business, 51, 600-611.

Luo, Y. and Peng, M. (1999). 'Learning to compete in a transitional economy: Experience, environment, and performance'. Journal of International Business Studies, 30, 269-295.

Mariano, S., Casey, A. and Olivera, F. (2018). 'Managers and organizational forgetting: A synthesis'. The Learning Organization, 25(3): 169-179.

March, J. G. (1991). 'Exploration and exploitation in organizational learning'. Organization Science, 2, 71-87.

March, J. G. (2010). 'The ambiguities of experience'. Ittaca: Cornell University Press.

Mellahi, K. (2003). 'The de-internationalization process: A case study of Marks and Spencer'. In C. Wheeler, F. McDonald, \& I. Greaves. Internationalization: Firm strategies and management: 150162. Hampshire: Palgrave Macmillan.

Mellahi, K., Frynas, J. G., Sun, P., \& Siegel, D. (2016). 'A review of the nonmarket strategy literature: Toward a multi-theoretical integration'. Journal of Management, 42, 143-173.

Meschi, P. X., Ricard, A. and Moore, E. T. (2017). Fast and furious or slow and cautious? The joint impact of age at internationalization, speed, and risk diversity on the survival of exporting firms. Journal of International Management, 23(3): 279-291.

Meyer, K. E., Estrin, S., Bhaumik, S. K. and Peng, M. W. (2009). 'Institutions, resources, and entry strategies in emerging economies'. Strategic Management Journal, 30, 61-80.

Millar, C. C. J. M., Eldomiaty, T. I., Choi, C. J. and Hilton, B. (2005). 'Corporate governance and institutional transparency in emerging markets'. Journal of Business Ethics, 1-2, 163-174.

Miller, G. (1992). 'Managerial Dilemmas'. Cambridge, UK: Cambridge University Press.

Nonaka, I. and Takeuchi, N. (1995). 'The knowledge creating company'. Oxford: Oxford University Press.

North, D. (1990). 'Institutions, Institutional Change and Economic Performance'. Cambridge: Cambridge University Press.

Noteboom, B. (2007). 'Social capital, institutions and trust'. Review of Social Economy, 65, 29-53.

Padmanabhan, P. and Rao, C. K. (1999). 'Decision specific experience in foreign ownership and establishment strategies: Evidence from Japanese firms'. Journal of International Business Studies, 30, 25-43.

Petersen, B., Welch, D. E. and Welch, L. S. (2000). 'Creating meaningful switching options in international operations. Long Range Planning, 33, 688-705.

Putzhammer, M., Fainshmidt, S., Puck, J. and Slangen, A. (2018). 'To elevate or to duplicate? Experiential learning, host-country institutions, and MNE post-entry commitment increase'. Journal of World Business, 53, 568-580. 
Quinn, R. E. and Cameron, K. S. (1988). 'Paradox and transformation: A dynamic theory of organization and management'. In Quinn R. E. and Cameron K. S. (Eds.), Paradox and transformation. Toward a theory of change in organization and management, pp. 289308. Cambndge, Massachusetts: Ballinger.

Sapienza, H. J., Autio, E., George, G. and Zahra, S. A. (2006). 'A capabilities perspective on the effects of early internationalization on firm survival and growth'. Academy of Management Review, 31, 914-933.

Saviotti, P. P. (1998). 'On the dynamics of appropriability, of tacit and of codified knowledge.' Research Policy, 26, 843-856.

Schulz, M. (2001). 'The uncertain relevance of newness: Organizational learning and knowledge flows'. Academy of Management Journal, 44, 661-681.

Shaver, J. M. (2013). 'Do we really need more entry mode studies?' Journal of International Business Studies, 44, 23-27.

Simonin, B. L. (1999). 'Ambiguity and the process of knowledge transfer in strategic alliances'. Strategic Management Journal, 20: 595-623.

Smith, W. K. and Lewis, M. W. (2011). 'Toward a theory of paradox: A dynamic equilibrium model of organizing'. Academy of Management Review, 36, 381-403.

Surdu, I., Mellahi, K. and Glaister, K.W. (2015). 'Learning and institutional change: Implications for foreign market re-entry commitment', Academy of Management Proceedings, January, 16808.

Surdu, I. and Mellahi, K. (2016). 'Theoretical foundations of equity based foreign market entry decisions: A review of the literature and recommendations for future research'. International Business Review, 25, 1169-1184.

Surdu, I., Mellahi, K. and Glaister, K. (2018a). 'Emerging market multinationals' international equitybased entry mode strategies: Review of theoretical foundations and future directions'. International Marketing Review, 35: 342-359.

Surdu, I., Mellahi, K. and Glaister, K. W. (2018b). 'Once bitten, not necessarily shy? Determinants of foreign market re-entry commitment strategies'. Journal of International Business Studies. DOI: https://doi.org/10.1057/s41267-018-0167-3.

Tan, D., Hung, S.-C. and Liu, N. (2007). 'The timing of entry into a new market: An empirical study of Taiwanese firms in China'. Management and Organization Review, 3, 227-254.

Tan, H. and Mathews, J. A. (2015). 'Accelerated internationalization and resource leverage strategizing: The case of Chinese wind turbine manufacturers'. Journal of World Business, 50, 417-427.

Teagarden, M. B., Von Glinow, M. A. and Mellahi, K. (2018). 'Contextualizing international business research: Enhancing rigor and relevance'. Journal of World Business, 53, 303-306.

Townsend, D. M. and Hart, T. A. (2008). 'Perceived institutional ambiguity and the choice of organizational form in social entrepreneurial ventures'. Entrepreneurship Theory and Practice, 32: 685-700. 
Tsang, E. and Zahra, S. (2008). 'Organizational unlearning'. Human Relations, 61(10), 1435-1462.

Vissak, T. and Francioni, B. (2013). 'Serial nonlinear internationalization in practice: A case study'. International Business Review, 22, 951-962.

Vissak, T. and Francioni, B. (2015). 'Chinese multinationals' entry, exit and re-entry patterns: Survey evidence'. In Marinov, M. (Eds.), Experiences of emerging economy firms, pp. 32-53. London: Palgrave Macmillan.

Wan, W. P. and Hokisson, R. E. (2003). 'Home country environments, corporate diversification strategies, and firm performance. Academy of Management Journal, 46, 27-45.

Welch, C. L. and Welch, L. S. (2009). 'Re-Internationalisation: Exploration and conceptualisation'. International Business Review, 18, 567-577.

Xia, J., Boal, K. and Delios, A. (2009). 'When experience meets national institutional environmental change: Foreign entry attempts of U.S. firms in the Central and Eastern European region'. Strategic Management Journal, 30, 1286-1309.

Zeng, Y., Shenkar, O., Lee, S.-H. and Song, S. (2013). 'Cultural differences, MNE learning abilities, and the effect of experience on subsidiary mortality in a dissimilar culture: Evidence from Korean MNEs'. Journal of International Business Studies, 44, 42-65.

Zhou, L. and Wu, A. (2014). 'Earliness of internationalization and performance outcomes: Exploring the moderating effects of venture age and international commitment'. Journal of World Business, 49, 132-142.

Zhou, N. and Guillén, M. F. (2015). 'From home country to home base: A dynamic approach to the liability of foreignness'. Strategic Management Journal, 36, 907-917.

Zucchella, A., Palamara, G. and Denicolai, S. (2007). 'The drivers of the early internationalization of the firm'. Journal of World Business, 42, 268-280. 


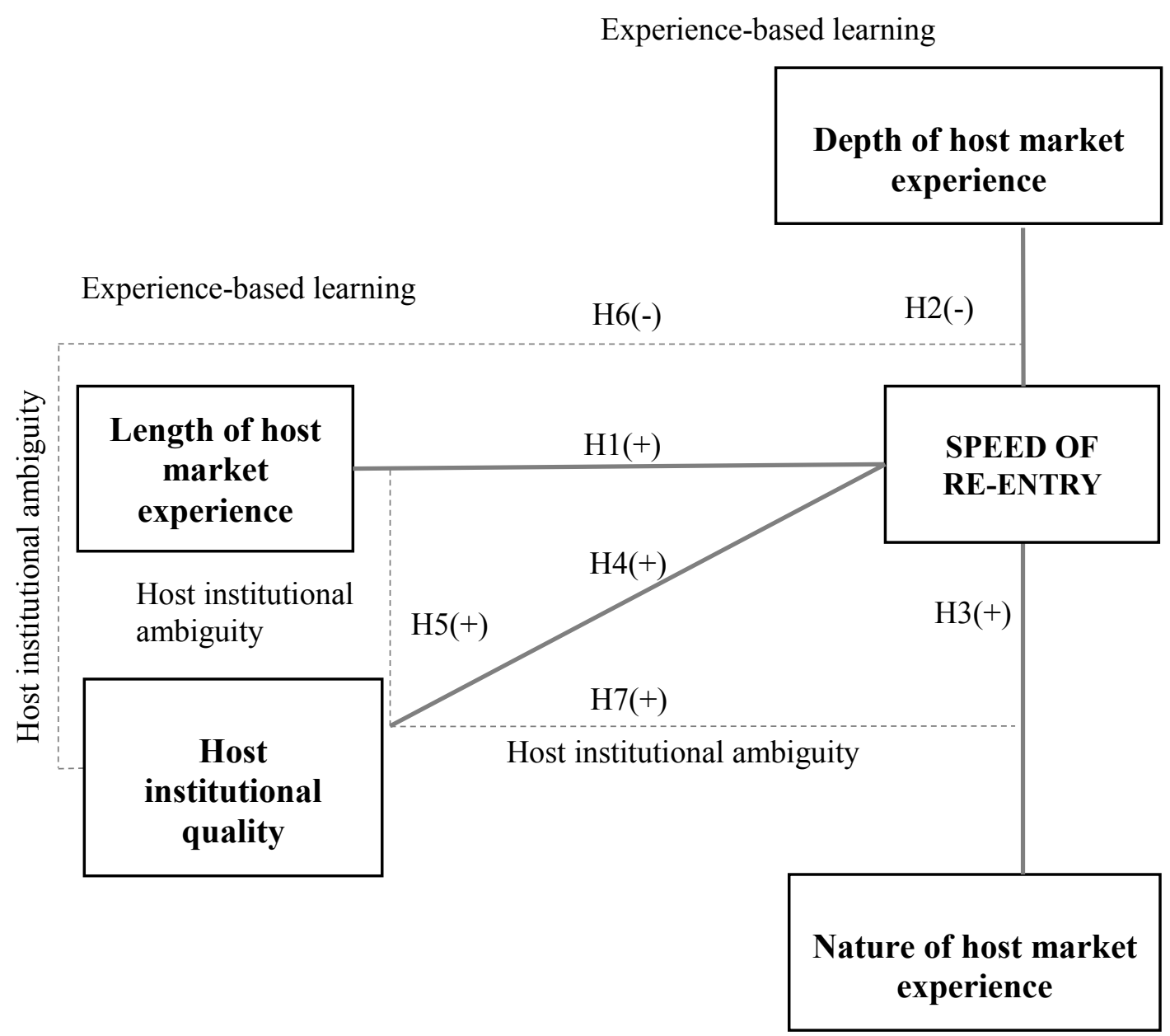

Experience-based learning

Figure I. A conceptualisation of the determinants of foreign market re-entry speed 
Table I. Sample description of foreign market re-entry events $(N=1,020)$

\begin{tabular}{|c|c|c|}
\hline & No. of re-entry events & $\%$ \\
\hline \multicolumn{3}{|l|}{ Panel A: Time period distribution } \\
\hline $1980 \mathrm{~s}$ & 32 & 3.1 \\
\hline $1990 \mathrm{~s}$ & 173 & 17.0 \\
\hline $2000-2010$ & 350 & 34.3 \\
\hline 2011-2016 & 465 & 45.6 \\
\hline \multicolumn{3}{|l|}{ Panel B: Host market re-entered (top 5) } \\
\hline India & 147 & 14.4 \\
\hline China & 76 & 7.5 \\
\hline South Africa & 74 & 7.3 \\
\hline US & 67 & 6.6 \\
\hline UK & 52 & 5.1 \\
\hline \multicolumn{3}{|c|}{ Panel C: Home market of re-entrant (top 5) } \\
\hline US & 312 & 30.6 \\
\hline UK & 120 & 5.9 \\
\hline Japan & 87 & 8.5 \\
\hline Italy & 56 & 5.5 \\
\hline Germany & 49 & 4.8 \\
\hline \multicolumn{3}{|l|}{ Panel D: Major industries } \\
\hline Automotive & 209 & 20.5 \\
\hline Financial services & 171 & 16.8 \\
\hline Retail & 113 & 11.1 \\
\hline Consumer electronics & 85 & 8.3 \\
\hline \multicolumn{3}{|l|}{ Home - Host Location } \\
\hline EU - EU & 130 out of $413 \mathrm{EU}$ firm re-entrants & 12.7 \\
\hline N AM - N AM & 6 out of 335 North American firm re-entrants & 0.59 \\
\hline S AM - S AM & 2 out of 8 South American re-entrants & 0.10 \\
\hline ASIA - ASIA & 137 out of 223 Asian firm re-entrants & 13.4 \\
\hline Australia and NZ - Australia and NZ & 4 out of 19 Autralian and NZ firm re-entrants & 0.39 \\
\hline Africa - Africa & 10 out of 22 African firm re-entrants & 0.98 \\
\hline
\end{tabular}


Table II. Descriptive statistics and correlation coefficients for speed of re-entry $\left({ }^{* * *} \mathrm{p}<0.001 ;{ }^{* *} \mathrm{p}<0.01 ;{ }^{*} \mathrm{p}<0.05\right)$

\begin{tabular}{|c|c|c|c|c|c|c|c|c|c|c|c|c|c|c|c|c|c|c|c|c|c|c|c|c|c|c|c|}
\hline Variables & $\begin{array}{l}\text { Std. } \\
\text { Dev. }\end{array}$ & Mean & $\mathrm{N}$ & 1 & 2 & 3 & 4 & 5 & 6 & 7 & 8 & 9 & 10 & 11 & 12 & 13 & 14 & 15 & 16 & 17 & 18 & 19 & 20 & 21 & 22 & 23 & 24 \\
\hline (1) EXPERIENCE_LENGTH & 21.49 & 18.13 & 975 & 1 & & & & & & & & & & & & & & & & & & & & & & & \\
\hline (2) EXPORTS & 0.48 & 0.37 & 937 & .01 & 1 & & & & & & & & & & & & & & & & & & & & & & \\
\hline (3) NONEQ_ALLIANCES & 0.36 & 0.16 & 937 & $-.08^{*}$ & .10 & 1 & & & & & & & & & & & & & & & & & & & & & \\
\hline (4) JV & 0.38 & 0.18 & 937 & $-.06^{*}$ & $.07^{*}$ & .28 & 1 & & & & & & & & & & & & & & & & & & & & \\
\hline (5) WOS & 0.45 & 0.28 & 937 &.$_{* *}^{.11}$ & $\begin{array}{r}-.19 \\
* *\end{array}$ & $\begin{array}{r}-.20 \\
* *\end{array}$ & $\begin{array}{l}.09 \\
* *\end{array}$ & 1 & & & & & & & & & & & & & & & & & & & \\
\hline (6) POORMKT_PERFORMANCE & 0.48 & 0.62 & 975 & -.07 & $\begin{array}{l}.09 \\
* *\end{array}$ & .04 & -.13 & -.02 & 1 & & & & & & & & & & & & & & & & & & \\
\hline (7) POORMODE_PERFORMANCE & 0.40 & 0.20 & 975 & -.13 & $\stackrel{-.08}{*}$ & .06 & .28 & -.21 & -.44 & 1 & & & & & & & & & & & & & & & & & \\
\hline (8) INST_QUAL_Size of government & 1.35 & 5.97 & 877 & -.04 & .03 & .07* & .02 & -.01 & -.02 & $.08^{*}$ & 1 & & & & & & & & & & & & & & & & \\
\hline $\begin{array}{l}\text { (9) INST_QUAL_Legal system and } \\
\text { IPR }\end{array}$ & 1.80 & 6.11 & 877 & $-.07^{*}$ & .28 & -.00 & .10 & .03 & .27 & -.00 & -.01 & 1 & & & & & & & & & & & & & & & \\
\hline (10) INST_QUAL_Sound money & 2.00 & 7.67 & 877 & -.00 & .17 & .01 & ${ }_{* *}^{.09}$ & .03 & .15 & .01 & .01 & $\begin{array}{l}.60 \\
* *\end{array}$ & 1 & & & & & & & & & & & & & & \\
\hline (11) INST_QUAL_Freedom to trade & 1.95 & 6.73 & 877 & -.06 & .25 & .03 & .14 & -.00 & .21 & .04 & .14 & $\begin{array}{l}.76 \\
* *\end{array}$ & $\begin{array}{l}.65 \\
{ }_{* *}\end{array}$ & 1 & & & & & & & & & & & & & \\
\hline (12) INST_QUAL_Regulation & 1.47 & 6.41 & 877 & -.04 & .23 & .06 & $\begin{array}{l}.09 \\
* *\end{array}$ & .03 & .17 & .06 & .21 & $\begin{array}{l}.66 \\
{ }_{* *}\end{array}$ & $\begin{array}{l}.59 \\
* *\end{array}$ & $\begin{array}{l}.67 \\
* *\end{array}$ & 1 & & & & & & & & & & & & \\
\hline (13) LNSIZE & 1.32 & 3.40 & 949 & .21 & -.09 & -.01 & -.01 & .01 & $-.08^{*}$ & -.01 & -.02 & -.12 & $\begin{array}{r}-.09 \\
* *\end{array}$ & -.11 & -.15 & 1 & & & & & & & & & & & \\
\hline (14) AGE & 51.82 & 68.48 & 974 & $\begin{array}{l}.38 \\
* *\end{array}$ & -.09 & -.02 & .05 & $-.08 *$ & $\stackrel{-.08}{* *}$ & -.03 & -.01 & -.16 & -.17 & -.16 & $\begin{array}{r}-15 \\
* *\end{array}$ & $\begin{array}{l}.32 \\
* *\end{array}$ & 1 & & & & & & & & & & \\
\hline (15) NCOUNTRY_INT & 47.62 & 59.25 & 869 & $\begin{array}{l}.05 \\
* *\end{array}$ & .00 & -.02 & -.03 & ${ }_{* *}^{.16}$ & $-.08^{*}$ & .01 & .03 & -.15 & -.13 & -.17 & -.12 & .36 & ${ }_{* *}^{.11}$ & 1 & & & & & & & & & \\
\hline (16) NCOUNTRY_HOST & 7.80 & 10.14 & 875 & .04 & .03 & .01 & -.04 & .05 & .01 & -.03 & -.05 & -.10 & -.06 & -.12 & -.12 & $\begin{array}{l}.26 \\
* *\end{array}$ & .06 & ${ }_{* *}^{.34}$ & 1 & & & & & & & & \\
\hline (17) NYEARS_INT & 35.56 & 44.96 & 965 & .47 & $-.07 *$ & -.05 & -.03 & $.06^{*}$ & -.04 & -.05 & .02 & $\begin{array}{l}.18 \\
* *\end{array}$ & -.14 & -.19 & -.15 & .37 & .49 & $\begin{array}{l}.33 \\
* *\end{array}$ & .21 & 1 & & & & & & & \\
\hline (18) NYEARS_HOST & 30.16 & 32.66 & 958 & $\begin{array}{l}.43 \\
* *\end{array}$ & -.05 & -.06 & .00 & .02 & .00 & -.06 & -.01 & -.11 & -.06 & -.13 & $\begin{array}{r}-.09 \\
* *\end{array}$ & .32 & .47 & ${ }_{* *}^{26}$ & .21 & $\begin{array}{l}.78 \\
* *\end{array}$ & 1 & & & & & & \\
\hline (19) REG & 0.47 & 0.33 & 975 & .01 & .79 & -.05 & .05 & -.05 & .05 & -.06 & $\begin{array}{l}-.11 \\
* *\end{array}$ & $.07 *$ & .06 & $.06^{*}$ & .01 & -.10 & -.13 & $\begin{array}{r}-.24 \\
* *\end{array}$ & .03 & -.22 & -.10 & 1 & & & & & \\
\hline (20) PRIOR_PRESENCE & 0.41 & 0.22 & 975 & $\begin{array}{l}.10 \\
* *\end{array}$ & .11 & -.03 & .05 & $\begin{array}{l}.10 \\
* *\end{array}$ & .14 & -.03 & .05 & $\begin{array}{l}.14 \\
* *\end{array}$ & $.06^{*}$ & $\begin{array}{l}.09 \\
* *\end{array}$ & $\begin{array}{l}.08 \\
* *\end{array}$ & $\begin{array}{l}.26 \\
* *\end{array}$ & ${ }_{* *}^{.11}$ & $\begin{array}{l}.27 \\
* *\end{array}$ & ${ }_{* *}^{.12}$ & $\begin{array}{l}.19 \\
* *\end{array}$ & $\begin{array}{l}.19 \\
* *\end{array}$ & -.05 & 1 & & & & \\
\hline (21) AUTOMOTIVE & 0.40 & 0.21 & 1020 & .10 & ${ }_{* *}^{26}$ & $-{ }_{* *}^{-19}$ & -.02 & -.12 & .02 & ${ }_{* *}^{.10}$ & .19 & .11 & -.04 & -.05 & $\begin{array}{r}-.08 \\
*\end{array}$ & .20 & .00 & .21 & .44 & .25 & .20 & $\begin{array}{l}-.13 \\
{ }_{* *}\end{array}$ & .18 & 1 & & & \\
\hline (22) RETAIL & 0.31 & 0.11 & 1020 & -.12 & ${ }_{* *}^{-.13}$ & .11 & -.04 & .09 & .05 & $\begin{array}{l}.09 \\
* *\end{array}$ & -.05 & .09 & .09 & .10 & ${ }_{* *}^{.09}$ & -.19 & -.03 & $\begin{array}{l}-.10 \\
{ }_{* *}\end{array}$ & -.16 & $\begin{array}{c}-.17 \\
* *\end{array}$ & $\begin{array}{r}-16 \\
{ }_{* *}\end{array}$ & .04 & -.14 & $\begin{array}{l}-.18 \\
* *\end{array}$ & 1 & & \\
\hline (23) FINANCIAL SERVICES & 0.37 & 0.17 & 1020 & .19 & -.15 & ${ }_{* *}^{-17}$ & $.07 *$ & .24 & $\begin{array}{r}-.09 \\
* *\end{array}$ & -.12 & -.04 & -.13 & -.05 & $\begin{array}{r}-.09 \\
* *\end{array}$ & -.09 & .19 & .34 & -.10 & -.23 & .21 & .21 & .06 & -.05 & $\begin{array}{r}-.23 \\
* *\end{array}$ & -.16 & 1 & \\
\hline (24) CONSUMER ELECTRONICS & 0.33 & 0.12 & 1020 & -03 & .19 & -.09 & -.05 & $\begin{array}{r}-.09 \\
* *\end{array}$ & $\begin{array}{l}.09 \\
{ }_{* *}\end{array}$ & $\stackrel{-06}{*}$ & .02 & .05 & -.00 & .01 & .05 & -.02 & $\begin{array}{r}-.09 \\
* *\end{array}$ & $.07 *$ & .04 & -.04 & $-.07^{*}$ & .03 & ${ }_{* *}^{.18}$ & -.19 & -.13 & -.17 & 1 \\
\hline
\end{tabular}


Table III: COX proportional hazard of re-entry within 2 years

\begin{tabular}{|c|c|c|c|c|c|c|c|c|c|c|c|c|c|c|c|c|}
\hline \multirow[t]{2}{*}{ Variables } & \multicolumn{2}{|c|}{ Model 1} & \multicolumn{2}{|c|}{ Model 2} & \multicolumn{2}{|c|}{ Model 3} & \multicolumn{2}{|c|}{ Model 4} & \multicolumn{2}{|c|}{ Model 5} & \multicolumn{2}{|c|}{ Model 6} & \multicolumn{2}{|c|}{ Model 7} & \multicolumn{2}{|c|}{ Model 8} \\
\hline & $\begin{array}{c}\beta \\
\text { (sig.) }\end{array}$ & S.E. & $\begin{array}{c}\beta \\
\text { (sig.) }\end{array}$ & S.E. & $\begin{array}{c}\beta \\
(\text { sig. })\end{array}$ & S.E. & $\begin{array}{c}\beta \\
\text { (sig.) }\end{array}$ & S.E. & $\begin{array}{c}\beta \\
(\text { sig. })\end{array}$ & S.E. & $\begin{array}{c}\beta \\
(\text { sig.) }\end{array}$ & S.E. & $\begin{array}{c}\beta \\
(\text { sig. })\end{array}$ & S.E. & $\begin{array}{c}\beta \\
(\text { sig. })\end{array}$ & S.E. \\
\hline EXPERIENCE_LENGTH & & & $\begin{array}{r}-0.009 \\
(0.060)\end{array}$ & $(0.005)$ & $\begin{array}{r}-0.008 \\
(0.105)\end{array}$ & $(0.005)$ & $\begin{array}{r}-0.004 \\
(0.398)\end{array}$ & $(0.005)$ & $\begin{array}{r}-0.005 \\
(0.297)\end{array}$ & $(0.005)$ & $\begin{array}{r}-0.007 \\
(0.179)\end{array}$ & $(0.005)$ & $\begin{array}{r}-0.005 \\
(0.309)\end{array}$ & $(0.005)$ & $\begin{array}{r}-0.004 \\
(0.365)\end{array}$ & $(0.005)$ \\
\hline EXPORTS vs. JV ${ }^{\mathrm{a}}$ & & & & & $\begin{array}{l}-0.428 \\
(0.021)\end{array}$ & $(0.185)$ & $\begin{array}{c}0.151 \\
(0.433)\end{array}$ & $(0.192)$ & $\begin{array}{l}-0.175 \\
(0.370)\end{array}$ & $(0.195)$ & $\begin{array}{c}-0.172 \\
(0.378)\end{array}$ & $(0.195)$ & $\begin{array}{l}-0.079 \\
(0.700)\end{array}$ & $(0.204)$ & $\begin{array}{c}0.147 \\
(0.453)\end{array}$ & $(0.197)$ \\
\hline NONEQ_ALLIANCES vs. JV ${ }^{\mathrm{a}}$ & & & & & $\begin{array}{l}-0.600 \\
(0.009)\end{array}$ & $(0.231)$ & $\begin{array}{c}0.481 \\
(0.041)\end{array}$ & $(0.235)$ & $\begin{array}{r}-0.515 \\
(0.030)\end{array}$ & $(0.237)$ & $\begin{array}{r}-0.506 \\
(0.033)\end{array}$ & $(0.237)$ & $\begin{array}{l}-0.350 \\
(0.161)\end{array}$ & $(0.234)$ & $\begin{array}{c}0.485 \\
(0.042)\end{array}$ & $(0.238)$ \\
\hline WOS vs. JV ${ }^{\mathrm{a}}$ & & & & & $\begin{array}{l}-0.558 \\
(0.007)\end{array}$ & $(0.205)$ & $\begin{array}{c}0.176 \\
(0.421)\end{array}$ & $(0.219)$ & $\begin{array}{l}-0.170 \\
(0.439)\end{array}$ & $(0.220)$ & $\begin{array}{r}-0.196 \\
(0.374)\end{array}$ & $(0.221)$ & $\begin{array}{l}-0.151 \\
(0.518)\end{array}$ & $(0.151)$ & $\begin{array}{c}0.151 \\
(0.494)\end{array}$ & $(0.221)$ \\
\hline POORMKT_PERFORMANCE ${ }^{\mathrm{b}}$ & & & & & & & $\begin{array}{c}0.484 \\
(0.013)\end{array}$ & $(0.195)$ & $\begin{array}{c}0.210 \\
(0.294)\end{array}$ & $(0.200)$ & $\begin{array}{c}0.193 \\
(0.338)\end{array}$ & $(0.201)$ & $\begin{array}{c}0.226 \\
(0.258)\end{array}$ & $(0.200)$ & $\begin{array}{c}0.248 \\
(0.220)\end{array}$ & $(0.202)$ \\
\hline POORMODE_PERFORMANCE ${ }^{\mathrm{b}}$ & & & & & & & $\begin{array}{c}1.158 \\
(0.000)\end{array}$ & $(0.211)$ & $\begin{array}{c}0.921 \\
(0.000)\end{array}$ & $(0.212)$ & $\begin{array}{c}0.896 \\
(0.000)\end{array}$ & $(0.213)$ & $\begin{array}{c}0.953 \\
(0.000)\end{array}$ & $(0.213)$ & $\begin{array}{c}0.934 \\
(0.000)\end{array}$ & $(0.216)$ \\
\hline INST_QUAL (1) & & & & & & & & & $\begin{array}{c}0.271 \\
(0.002)\end{array}$ & $(0.087)$ & $\begin{array}{c}0.244 \\
(0.033)\end{array}$ & $(0.113)$ & $\begin{array}{r}-0.446 \\
(0.337)\end{array}$ & $(0.465)$ & $\begin{array}{l}-0.106 \\
(0.685)\end{array}$ & $(0.260)$ \\
\hline INST_QUAL (2) & & & & & & & & & $\begin{array}{c}0.130 \\
(0.098)\end{array}$ & $(0.078)$ & $\begin{array}{c}0.001 \\
(0.995)\end{array}$ & $(0.114)$ & $\begin{array}{l}-0.565 \\
(0.196)\end{array}$ & $(0.437)$ & $\begin{array}{c}0.110 \\
(0.657)\end{array}$ & $(0.249)$ \\
\hline $\begin{array}{l}\text { INST_QUAL (1) } \mathrm{x} \\
\text { EXPERIENCE LENGTH }\end{array}$ & & & & & & & & & & & $\begin{array}{c}0.002 \\
(0.621)\end{array}$ & $(0.005)$ & & & & \\
\hline $\begin{array}{l}\text { INST_QUAL }(2) \times \\
\text { EXPERIENCE LENGTH }\end{array}$ & & & & & & & & & & & $\begin{array}{c}0.014 \\
(0.895)\end{array}$ & $(0.102)$ & & & & \\
\hline $\begin{array}{l}\text { INST_QUAL (1) x EXPORTS } \\
\text { VS. JV }\end{array}$ & & & & & & & & & & & & & $\begin{array}{r}-0.308 \\
(0.179)\end{array}$ & $(0.229)$ & & \\
\hline $\begin{array}{l}\text { INST_QUAL (1) x } \\
\text { NONEQ_ALLIANCES vs. JV }\end{array}$ & & & & & & & & & & & & & $\begin{array}{l}-0.536 \\
(0.047)\end{array}$ & $(0.270)$ & & \\
\hline INST_QUAL (1) x WOS vs. JV ${ }^{\mathrm{a}}$ & & & & & & & & & & & & & $\begin{array}{r}-0.092 \\
(0.696)\end{array}$ & $(0.236)$ & & \\
\hline $\begin{array}{l}\text { INST_QUAL (2) x EXPORTS } \\
\text { VS. JV }\end{array}$ & & & & & & & & & & & & & $\begin{array}{l}-0.308 \\
(0.154)\end{array}$ & $(0.216)$ & & \\
\hline $\begin{array}{l}\text { INST_QUAL (2) x } \\
\text { NONEQ_ALLIANCES vs. JV }\end{array}$ & & & & & & & & & & & & & $\begin{array}{l}-0.224 \\
(0.363)\end{array}$ & $(0.247)$ & & \\
\hline INST_QUAL (2) x WOS vs. JV & & & & & & & & & & & & & $\begin{array}{r}-0.409 \\
(0.076)\end{array}$ & $(0.231)$ & & \\
\hline $\begin{array}{l}\text { INST_QUAL (1) x } \\
\text { POORMKT_PERFORMANCE }\end{array}$ & & & & & & & & & & & & & & & $\begin{array}{r}-0.301 \\
(0.151)\end{array}$ & $(0.210)$ \\
\hline $\begin{array}{l}\text { INST_QUAL (1) } \mathrm{x} \\
\text { POORMODE_PERFORMANCE }\end{array}$ & & & & & & & & & & & & & & & $\begin{array}{l}-0.290 \\
(0.194)\end{array}$ & $(0.223)$ \\
\hline $\begin{array}{l}\text { INST_QUAL_(2) x } \\
\text { POORMKT_PERFORMANCE }\end{array}$ & & & & & & & & & & & & & & & $\begin{array}{c}-0.068 \\
(0.747)\end{array}$ & $(0.210)$ \\
\hline $\begin{array}{l}\text { INST_QUAL }(2) \mathrm{x} \\
\text { POORMODE_PERFORMANCE } \\
\text { Controls }\end{array}$ & & & & & & & & & & & & & & & $\begin{array}{c}0.035 \\
(0.874)\end{array}$ & $(0.220)$ \\
\hline LNSIZE & $\begin{array}{c}0.019 \\
(0.749)\end{array}$ & $(0.058)$ & $\begin{array}{c}0.019 \\
(0.751)\end{array}$ & $(0.059)$ & $\begin{array}{c}0.014 \\
(0.811)\end{array}$ & $(0.059)$ & $\begin{array}{c}0.016 \\
(0.780)\end{array}$ & $(0.059)$ & $\begin{array}{c}0.025 \\
(0.680)\end{array}$ & $(0.060)$ & $\begin{array}{c}0.022 \\
(0.721)\end{array}$ & $(0.061)$ & $\begin{array}{c}0.023 \\
(0.708)\end{array}$ & $(0.061)$ & $\begin{array}{c}0.028 \\
(0.646)\end{array}$ & $(0.061)$ \\
\hline AGE & $\begin{array}{c}0.002 \\
(0.343)\end{array}$ & $(0.002)$ & $\begin{array}{c}0.002 \\
(0.295)\end{array}$ & $(0.002)$ & $\begin{array}{c}0.001 \\
(0.486)\end{array}$ & $(0.002)$ & $\begin{array}{c}0.001 \\
(0.507)\end{array}$ & $(0.002)$ & $\begin{array}{c}0.001 \\
(0.487)\end{array}$ & $(0.002)$ & $\begin{array}{c}0.001 \\
(0.461)\end{array}$ & $(0.002)$ & $\begin{array}{c}0.001 \\
(0.470)\end{array}$ & $(0.002)$ & $\begin{array}{c}0.001 \\
(0.508)\end{array}$ & $(0.002)$ \\
\hline NCOUNTRY_INT & $\begin{array}{l}-0.001 \\
(0.614)\end{array}$ & $(0.002)$ & $\begin{array}{l}-0.001 \\
(0.591)\end{array}$ & $(0.002)$ & $\begin{array}{c}0.000 \\
(0.886)\end{array}$ & $(0.002)$ & $\begin{array}{c}0.001 \\
(0.603)\end{array}$ & $(0.002)$ & $\begin{array}{l}0.001 \\
(0.415)\end{array}$ & $(0.002)$ & $\begin{array}{c}0.002 \\
(0.399)\end{array}$ & $(0.002)$ & $\begin{array}{c}0.001 \\
(0.361)\end{array}$ & $(0.002)$ & $\begin{array}{c}0.001 \\
(0.426)\end{array}$ & $(0.002)$ \\
\hline NCOUNTRY_HOST & $\begin{array}{l}-0.004 \\
(0.675)\end{array}$ & $(0.011)$ & $\begin{array}{l}-0.005 \\
(0.627)\end{array}$ & $(0.011)$ & $\begin{array}{l}-0.007 \\
(0.544)\end{array}$ & $(0.011)$ & $\begin{array}{l}-0.008 \\
(0.462)\end{array}$ & $(0.011)$ & $\begin{array}{l}-0.005 \\
(0.636)\end{array}$ & $(0.011)$ & $\begin{array}{l}-0.005 \\
(0.617)\end{array}$ & $(0.011)$ & $\begin{array}{l}-0.007 \\
(0.522)\end{array}$ & $(0.011)$ & $\begin{array}{l}-0.004 \\
(0.708)\end{array}$ & $(0.011)$ \\
\hline NYEARS & $\begin{array}{l}-0.152 \\
(0.131)\end{array}$ & $(0.100)$ & $\begin{array}{l}-0.069 \\
(0.520)\end{array}$ & $(0.108)$ & $\begin{array}{l}-0.067 \\
(0.536)\end{array}$ & $(0.109)$ & $\begin{array}{l}-0.094 \\
(0.379)\end{array}$ & $(0.107)$ & $\begin{array}{l}-0.058 \\
(0.592)\end{array}$ & $(0.109)$ & $\begin{array}{l}-0.054 \\
(0.617)\end{array}$ & $(0.109)$ & $\begin{array}{l}-0.049 \\
(0.652)\end{array}$ & $(0.109)$ & $\begin{array}{l}-0.066 \\
(0.546)\end{array}$ & $(0.110)$ \\
\hline REG & $\begin{array}{c}0.070 \\
(0.932)\end{array}$ & $(0.154)$ & $\begin{array}{c}0.070 \\
(0.648)\end{array}$ & $(0.154)$ & $\begin{array}{c}0.071 \\
(0.648)\end{array}$ & $(0.155)$ & $\begin{array}{c}0.144 \\
(0.355)\end{array}$ & $(0.156)$ & $\begin{array}{c}0.166 \\
(0.294)\end{array}$ & $(0.158)$ & $\begin{array}{c}0.181 \\
(0.253)\end{array}$ & $(0.159)$ & $\begin{array}{c}0.154 \\
(0.331)\end{array}$ & $(0.159)$ & $\begin{array}{c}0.133 \\
(0.402)\end{array}$ & $(0.159)$ \\
\hline PRIOR_PRESENCE & $\begin{array}{c}0.076 \\
(0.927)\end{array}$ & $(0.177)$ & $\begin{array}{c}0.070 \\
(0.690)\end{array}$ & $(0.176)$ & $\begin{array}{c}0.025 \\
(0.887)\end{array}$ & $(0.177)$ & $\begin{array}{l}-0.002 \\
(0.989)\end{array}$ & $(0.182)$ & $\begin{array}{l}-0.135 \\
(0.467)\end{array}$ & $(0.186)$ & $\begin{array}{l}-0.140 \\
(0.453)\end{array}$ & $(0.186)$ & $\begin{array}{l}-0.126 \\
(0.501)\end{array}$ & $(0.187)$ & $\begin{array}{l}-0.139 \\
(0.456)\end{array}$ & $(0.186)$ \\
\hline AUTOMOTIVE & $\begin{array}{l}-0.025 \\
(0.909)\end{array}$ & $(0.218)$ & $\begin{array}{l}-0.024 \\
(0.912)\end{array}$ & $(0.219)$ & $\begin{array}{l}-0.115 \\
(0.613)\end{array}$ & $(0.228)$ & $\begin{array}{l}-0.328 \\
(0.158)\end{array}$ & $(0.232)$ & $\begin{array}{l}-0.315 \\
(0.187)\end{array}$ & $(0.239)$ & $\begin{array}{l}-0.335 \\
(0.164)\end{array}$ & $(0.241)$ & $\begin{array}{l}-0.310 \\
(0.197)\end{array}$ & $(0.240)$ & $\begin{array}{l}-0.333 \\
(0.168)\end{array}$ & $(0.242)$ \\
\hline RETAIL & $\begin{array}{c}0.014 \\
(0.986)\end{array}$ & $(0.227)$ & $\begin{array}{l}-0.002 \\
(0.994)\end{array}$ & $(0.227)$ & $\begin{array}{c}0.040 \\
(0.862)\end{array}$ & $(0.229)$ & $\begin{array}{l}-0.117 \\
(0.610)\end{array}$ & $(0.229)$ & $\begin{array}{l}-0.127 \\
(0.582)\end{array}$ & $(0.231)$ & $\begin{array}{l}-0.124 \\
(0.592)\end{array}$ & $(0.231)$ & $\begin{array}{l}-0.170 \\
(0.465)\end{array}$ & $(0.233)$ & $\begin{array}{l}-0.124 \\
(0.594)\end{array}$ & $(0.232)$ \\
\hline FINANCIAL SERVICES & $\begin{array}{l}-0.427 \\
(0.086)\end{array}$ & $(0.248)$ & $\begin{array}{l}-0.378 \\
(0.126)\end{array}$ & $(0.247)$ & $\begin{array}{l}-0.335 \\
(0.184)\end{array}$ & $(0.252)$ & $\begin{array}{l}-0.219 \\
(0.384)\end{array}$ & $(0.252)$ & $\begin{array}{l}-0.101 \\
(0.692)\end{array}$ & $(0.256)$ & $\begin{array}{l}-0.126 \\
(0.624)\end{array}$ & $(0.257)$ & $\begin{array}{l}-0.044 \\
(0.867)\end{array}$ & $(0.261)$ & $\begin{array}{l}-0.065 \\
(0.802)\end{array}$ & $(0.258)$ \\
\hline CONSUMER ELECTRONICS & $\begin{array}{c}0.159 \\
(0.853)\end{array}$ & $(0.219)$ & $\begin{array}{l}0.167 \\
(0.447)\end{array}$ & $(0.219)$ & $\begin{array}{c}0.172 \\
(0.447)\end{array}$ & $(0.227)$ & $\begin{array}{c}0.132 \\
(0.561)\end{array}$ & $(0.228)$ & $\begin{array}{l}0.177 \\
(0.441)\end{array}$ & $(0.230)$ & $\begin{array}{c}0.178 \\
(0.440)\end{array}$ & $(0.230)$ & $\begin{array}{c}0.168 \\
(0.464)\end{array}$ & $(0.230)$ & $\begin{array}{c}0.179 \\
(0.438)\end{array}$ & $(0.231)$ \\
\hline $\mathrm{N}$ & \multicolumn{2}{|c|}{849} & \multicolumn{2}{|c|}{848} & \multicolumn{2}{|c|}{814} & \multicolumn{2}{|c|}{814} & \multicolumn{2}{|c|}{749} & \multicolumn{2}{|c|}{749} & \multicolumn{2}{|c|}{749} & \multicolumn{2}{|c|}{749} \\
\hline-2 Log Likelihood & \multicolumn{2}{|c|}{2767.9} & \multicolumn{2}{|c|}{2763.9} & \multicolumn{2}{|c|}{2710.7} & \multicolumn{2}{|c|}{2678.6} & \multicolumn{2}{|c|}{2614.9} & \multicolumn{2}{|c|}{2611.9} & 260 & & 261 & \\
\hline Chi-Square & $\begin{array}{r}9.8 \\
(0.5 \\
\end{array}$ & & $\begin{array}{l}12 . \\
(0.3\end{array}$ & $\begin{array}{r}752 \\
87) \\
\end{array}$ & $\begin{array}{l}22 . \\
0.0\end{array}$ & & $\begin{array}{l}59.4 \\
0.0\end{array}$ & & $\begin{array}{l}56.7 \\
(0.0 \\
\end{array}$ & & $\begin{array}{l}57 \\
(0 .\end{array}$ & & $\begin{array}{l}66 . \\
(0.6\end{array}$ & & $\begin{array}{l}58 . \\
0.0\end{array}$ & \\
\hline
\end{tabular}


Table IV: COX proportional hazard of re-entry within 5 years

\begin{tabular}{|c|c|c|c|c|c|c|c|c|c|c|c|c|c|c|c|c|}
\hline \multirow[t]{2}{*}{ Variables } & \multicolumn{2}{|c|}{ Model 1} & \multicolumn{2}{|c|}{ Model 2} & \multicolumn{2}{|c|}{ Model 3} & \multicolumn{2}{|c|}{ Model 4} & \multicolumn{2}{|c|}{ Model 5} & \multicolumn{2}{|c|}{ Model 6} & \multicolumn{2}{|c|}{ Model 7} & \multicolumn{2}{|c|}{ Model 8} \\
\hline & $\begin{array}{c}\beta \\
(\text { sig.) }\end{array}$ & S.E. & $\begin{array}{c}\beta \\
(\text { sig.) }\end{array}$ & S.E. & $\begin{array}{c}\beta \\
(\text { sig.) }\end{array}$ & S.E. & $\begin{array}{c}\beta \\
(\text { sig. })\end{array}$ & S.E. & $\begin{array}{c}\beta \\
(\text { sig.) }\end{array}$ & S.E. & $\begin{array}{c}\beta \\
\text { (sig.) }\end{array}$ & S.E. & $\begin{array}{c}\beta \\
(\text { sig.) }\end{array}$ & S.E. & $\begin{array}{c}\beta \\
(\text { sig.) }\end{array}$ & S.E. \\
\hline EXPERIENCE_LENGTH & & & $\begin{array}{r}-0.009 \\
(0.008)\end{array}$ & $(0.003)$ & $\begin{array}{l}-0.008 \\
(0.020)\end{array}$ & $(0.003)$ & $\begin{array}{l}-0.006 \\
(0.103)\end{array}$ & $(0.003)$ & $\begin{array}{l}-0.006 \\
(0.063)\end{array}$ & $(0.003)$ & $\begin{array}{l}-0.008 \\
(0.025)\end{array}$ & $(0.004)$ & $\begin{array}{l}-0.006 \\
(0.074)\end{array}$ & $(0.003)$ & $\begin{array}{r}-0.006 \\
(0.088)\end{array}$ & $(0.003)$ \\
\hline EXPORTS vs. JV ${ }^{\mathrm{a}}$ & & & & & $\begin{array}{l}-0.404 \\
(0.003)\end{array}$ & (0.134) & $\begin{array}{c}0.280 \\
(0.044)\end{array}$ & $(0.139)$ & $\begin{array}{l}-0.284 \\
(0.046)\end{array}$ & $(0.142)$ & $\begin{array}{c}0.285 \\
(0.047)\end{array}$ & $(0.143)$ & $\begin{array}{r}-0.215 \\
(0.143)\end{array}$ & $(0.147)$ & $\begin{array}{c}0.256 \\
(0.077)\end{array}$ & $(0.145)$ \\
\hline NONEQ_ALLIANCES vs. JV ${ }^{\mathrm{a}}$ & & & & & $\begin{array}{l}-0.443 \\
(0.006)\end{array}$ & $(0.160)$ & $\begin{array}{c}0.395 \\
(0.015)\end{array}$ & $(0.163)$ & $\begin{array}{l}-0.450 \\
(0.007)\end{array}$ & $(0.168)$ & $\begin{array}{c}0.440 \\
(0.009)\end{array}$ & $(0.168)$ & $\begin{array}{l}-0.290 \\
(0.090)\end{array}$ & $(0.171)$ & $\begin{array}{c}0.424 \\
(0.012)\end{array}$ & $(0.169)$ \\
\hline WOS vs. JV & & & & & $\begin{array}{l}-0.614 \\
(0.000)\end{array}$ & $(0.148)$ & $\begin{array}{c}0.431 \\
(0.006)\end{array}$ & $(0.156)$ & $\begin{array}{r}-0.385 \\
(0.014)\end{array}$ & $(0.157)$ & $\begin{array}{c}0.413 \\
(0.009)\end{array}$ & $(0.158)$ & $\begin{array}{l}-0.362 \\
(0.027)\end{array}$ & $(0.164)$ & $\begin{array}{c}0.364 \\
(0.022)\end{array}$ & $(0.159)$ \\
\hline POORMKT_PERFORMANCE ${ }^{\mathrm{b}}$ & & & & & & & $\begin{array}{c}0.333 \\
(0.008)\end{array}$ & $(0.126)$ & $\begin{array}{c}0.056 \\
(0.667)\end{array}$ & $(0.131)$ & $\begin{array}{c}0.037 \\
(0.778)\end{array}$ & $(0.132)$ & $\begin{array}{c}0.096 \\
(0.463)\end{array}$ & $(0.131)$ & $\begin{array}{c}0.079 \\
(0.551)\end{array}$ & $(0.133)$ \\
\hline POORMODE_PERFORMANCE ${ }^{\mathrm{b}}$ & & & & & & & $\begin{array}{c}0.006 \\
(0.103)\end{array}$ & $(0.003)$ & $\begin{array}{c}0.436 \\
(0.004)\end{array}$ & $(0.150)$ & $\begin{array}{r}-0.406 \\
(0.007)\end{array}$ & $(0.150)$ & $\begin{array}{c}0.483 \\
(0.001)\end{array}$ & $(0.151)$ & $\begin{array}{c}-0.192 \\
(0.221)\end{array}$ & $(0.157)$ \\
\hline INST_QUAL (1) & & & & & & & & & $\begin{array}{c}0.332 \\
(0.000)\end{array}$ & $(0.059)$ & $\begin{array}{c}0.290 \\
(0.000)\end{array}$ & $(0.078)$ & $\begin{array}{l}-0.557 \\
(0.089)\end{array}$ & $(0.327)$ & $\begin{array}{c}0.094 \\
(0.601)\end{array}$ & $(0.181)$ \\
\hline INST_QUAL (2) & & & & & & & & & $\begin{array}{c}0.071 \\
(0.177)\end{array}$ & $(0.053)$ & $\begin{array}{l}-0.069 \\
(0.328)\end{array}$ & $(0.071)$ & $\begin{array}{l}-0.417 \\
(0.162)\end{array}$ & $(0.298)$ & $\begin{array}{l}-0.012 \\
(0.942)\end{array}$ & $(0.167)$ \\
\hline $\begin{array}{l}\text { INST_QUAL (1) } \mathrm{x} \\
\text { EXPERIENCE_LENGTH }\end{array}$ & & & & & & & & & & & $\begin{array}{c}0.002 \\
(0.556)\end{array}$ & $(0.003)$ & & & & \\
\hline $\begin{array}{l}\text { INST_QUAL }(2) \mathrm{x} \\
\text { EXPERIENCE_LENGTH }\end{array}$ & & & & & & & & & & & $\begin{array}{c}0.010 \\
(0.005)\end{array}$ & $(0.004)$ & & & & \\
\hline $\begin{array}{l}\text { INST_QUAL (1) x EXPORTS vs. } \\
J^{\mathrm{a}}\end{array}$ & & & & & & & & & & & & & $\begin{array}{l}-0.389 \\
(0.016)\end{array}$ & $(0.162)$ & & \\
\hline $\begin{array}{l}\text { INST_QUAL (1) x } \\
\text { NONEQ_ALLIANCES vs. JV }\end{array}$ & & & & & & & & & & & & & $\begin{array}{l}-0.600 \\
(0.001)\end{array}$ & $(0.186)$ & & \\
\hline INST_QUAL (1) x WOS vs. JV & & & & & & & & & & & & & $\begin{array}{l}-0.200 \\
(0.233)\end{array}$ & $(0.167)$ & & \\
\hline $\begin{array}{l}\text { INST_QUAL (2) x EXPORTS vs. } \\
J^{\mathrm{a}}\end{array}$ & & & & & & & & & & & & & $\begin{array}{l}-0.221 \\
(0.136)\end{array}$ & $(0.148)$ & & \\
\hline $\begin{array}{l}\text { INST_QUAL (2) } \mathrm{x} \\
\text { NONEQ_ALLIANCES vs. JV }\end{array}$ & & & & & & & & & & & & & $\begin{array}{l}-0.273 \\
(0.087)\end{array}$ & $(0.160)$ & & \\
\hline INST_QUAL (2) x WOS vs. JV & & & & & & & & & & & & & $\begin{array}{l}-0.173 \\
(0.295)\end{array}$ & $(0.165)$ & & \\
\hline $\begin{array}{l}\text { INST_QUAL (1) } \mathrm{x} \\
\text { POORMKT_PERFORMANCE }\end{array}$ & & & & & & & & & & & & & & & $\begin{array}{l}-0.155 \\
(0.241)\end{array}$ & $(0.132)$ \\
\hline $\begin{array}{l}\text { INST_QUAL }(1) \mathrm{x} \\
\text { POORMODE_PERFORMANCE }\end{array}$ & & & & & & & & & & & & & & & $\begin{array}{l}-0.192 \\
(0.221)\end{array}$ & $(0.157)$ \\
\hline $\begin{array}{l}\text { INST_QUAL_(2) x } \\
\text { POORMKT_PERFORMANCE }\end{array}$ & & & & & & & & & & & & & & & $\begin{array}{c}-0.112 \\
(0.390)\end{array}$ & $(0.130)$ \\
\hline $\begin{array}{l}\text { INST_QUAL (2) } \mathrm{x} \\
\text { POORMODE_PERFORMANCE }\end{array}$ & & & & & & & & & & & & & & & $\begin{array}{l}-0.032 \\
(0.829)\end{array}$ & $(0.149)$ \\
\hline Controls & & & & & & & & & & & & & & & & \\
\hline LNSIZE & $\begin{array}{l}-0.108 \\
(0.006)\end{array}$ & $(0.040)$ & $\begin{array}{l}-0.107 \\
(0.007)\end{array}$ & $(0.040)$ & $\begin{array}{l}-0.104 \\
(0.009)\end{array}$ & $(0.040)$ & $\begin{array}{l}-0.102 \\
(0.011)\end{array}$ & $(0.040)$ & $\begin{array}{l}-0.087 \\
(0.038)\end{array}$ & $(0.042)$ & $\begin{array}{l}-0.092 \\
(0.029)\end{array}$ & $(0.042)$ & $\begin{array}{l}-0.083 \\
(0.049)\end{array}$ & $(0.042)$ & $\begin{array}{l}-0.086 \\
(0.041)\end{array}$ & $(0.042)$ \\
\hline AGE & $\begin{array}{c}0.001 \\
(0.377)\end{array}$ & $(0.001)$ & $\begin{array}{c}0.001 \\
(0.277)\end{array}$ & $(0.001)$ & $\begin{array}{l}(0.001) \\
(0.623)\end{array}$ & $(0.001)$ & $\begin{array}{c}0.001 \\
(0.576)\end{array}$ & $(0.001)$ & $\begin{array}{c}0.001 \\
(0.526)\end{array}$ & $(0.001)$ & $\begin{array}{c}0.001 \\
(0.499)\end{array}$ & $(0.001)$ & $\begin{array}{c}0.001 \\
(0.510)\end{array}$ & $(0.001)$ & $\begin{array}{c}0.001 \\
(0.559)\end{array}$ & $(0.001)$ \\
\hline NCOUNTRY_INT & $\begin{array}{l}-0.001 \\
(0.635)\end{array}$ & $(0.001)$ & $\begin{array}{l}-0.001 \\
(0.544)\end{array}$ & $(0.001)$ & $\begin{array}{c}0.000 \\
(0.872)\end{array}$ & $(0.001)$ & $\begin{array}{c}0.000 \\
(0.714)\end{array}$ & $(0.001)$ & $\begin{array}{c}0.001 \\
(0.336)\end{array}$ & $(0.001)$ & $\begin{array}{c}0.001 \\
(0.338)\end{array}$ & $(0.001)$ & $\begin{array}{c}0.001 \\
(0.334)\end{array}$ & $(0.001)$ & $\begin{array}{c}0.001 \\
(0.329)\end{array}$ & $(0.001)$ \\
\hline NCOUNTRY_HOST & $\begin{array}{l}-0.005 \\
(0.491)\end{array}$ & $(0.007)$ & $\begin{array}{l}-0.006 \\
(0.429)\end{array}$ & $(0.007)$ & $\begin{array}{l}-0.007 \\
(0.329)\end{array}$ & $(0.008)$ & $\begin{array}{l}-0.009 \\
(0.265)\end{array}$ & $(0.008)$ & $\begin{array}{l}-0.004 \\
(0.584)\end{array}$ & $(0.008)$ & $\begin{array}{l}-0.005 \\
(0.560)\end{array}$ & $(0.008)$ & $\begin{array}{l}-0.006 \\
(0.478)\end{array}$ & $(0.008)$ & $\begin{array}{l}-0.003 \\
(0.667)\end{array}$ & $(0.008)$ \\
\hline NYEARS & $\begin{array}{l}-0.157 \\
(0.026)\end{array}$ & $(0.070)$ & $\begin{array}{l}-0.074 \\
(0.325)\end{array}$ & $(0.075)$ & $\begin{array}{l}-0.056 \\
(0.465)\end{array}$ & $(0.077)$ & $\begin{array}{l}-0.077 \\
(0.312)\end{array}$ & $(0.076)$ & $\begin{array}{l}-0.029 \\
(0.707)\end{array}$ & $(0.078)$ & $\begin{array}{l}-0.026 \\
(0.742)\end{array}$ & $(0.078)$ & $\begin{array}{l}-0.029 \\
(0.706)\end{array}$ & $(0.078)$ & $\begin{array}{l}-0.032 \\
(0.679)\end{array}$ & $(0.078)$ \\
\hline REG & $\begin{array}{c}0.147 \\
(0.171)\end{array}$ & $(0.107)$ & $\begin{array}{c}0.141 \\
(0.190)\end{array}$ & $(0.107)$ & $\begin{array}{c}0.128 \\
(0.235)\end{array}$ & $(0.108)$ & $\begin{array}{c}0.154 \\
(0.157)\end{array}$ & $(0.109)$ & $\begin{array}{c}0.171 \\
(0.124)\end{array}$ & $(0.111)$ & $\begin{array}{c}0.189 \\
(0.091)\end{array}$ & $(0.112)$ & $\begin{array}{c}0.155 \\
(0.166)\end{array}$ & $(0.112)$ & $\begin{array}{c}0.151 \\
(0.177)\end{array}$ & $(0.112)$ \\
\hline PRIOR_PRESENCE & $\begin{array}{c}0.316 \\
(0.009)\end{array}$ & $(0.122)$ & $\begin{array}{c}0.306 \\
(0.012)\end{array}$ & $(0.121)$ & $\begin{array}{c}0.271 \\
(0.027)\end{array}$ & $(0.123)$ & $\begin{array}{c}0.221 \\
(0.077)\end{array}$ & $(0.125)$ & $\begin{array}{c}0.036 \\
(0.778)\end{array}$ & $(0.129)$ & $\begin{array}{c}0.028 \\
(0.829)\end{array}$ & $(0.129)$ & $\begin{array}{c}0.033 \\
(0.801)\end{array}$ & $(0.130)$ & $\begin{array}{c}0.028 \\
(0.827)\end{array}$ & $(0.129)$ \\
\hline AUTOMOTIVE & $\begin{array}{l}-0.023 \\
(0.885)\end{array}$ & $(0.156)$ & $\begin{array}{l}-0.010 \\
(0.952)\end{array}$ & $(0.157)$ & $\begin{array}{l}-0.122 \\
(0.458)\end{array}$ & $(0.164)$ & $\begin{array}{c}-0.230 \\
(0.168)\end{array}$ & $(0.166)$ & $\begin{array}{c}-0.218 \\
(0.203)\end{array}$ & $(0.169)$ & $\begin{array}{l}-0.224 \\
(0.195)\end{array}$ & $(0.173)$ & $\begin{array}{l}-0.198 \\
(0.251)\end{array}$ & $(0.172)$ & $\begin{array}{l}-0.238 \\
(0.170)\end{array}$ & $(0.174)$ \\
\hline RETAIL & $\begin{array}{c}0.011 \\
(0.945)\end{array}$ & $(0.161)$ & $\begin{array}{c}0.001 \\
(0.994)\end{array}$ & $(0.161)$ & $\begin{array}{c}0.025 \\
(0.879)\end{array}$ & $(0.162)$ & $\begin{array}{c}-0.074 \\
(0.651)\end{array}$ & $(0.163)$ & $\begin{array}{c}-0.146 \\
(0.379)\end{array}$ & $(0.166)$ & $\begin{array}{c}-0.152 \\
(0.361)\end{array}$ & $(0.166)$ & $\begin{array}{l}-0.177 \\
(0.292)\end{array}$ & $(0.168)$ & $\begin{array}{c}-0.142 \\
(0.394)\end{array}$ & $(0.167)$ \\
\hline FINANCIAL SERVICES & $\begin{array}{c}-0.012 \\
(0.938)\end{array}$ & $(0.160)$ & $\begin{array}{c}0.037 \\
(0.814)\end{array}$ & $(0.159)$ & $\begin{array}{c}0.056 \\
(0.737)\end{array}$ & $(0.168)$ & $\begin{array}{c}0.128 \\
(0.447)\end{array}$ & $(0.169)$ & $\begin{array}{c}0.228 \\
(0.193)\end{array}$ & $(0.175)$ & $\begin{array}{c}0.195 \\
(0.267)\end{array}$ & $(0.176)$ & $\begin{array}{c}0.249 \\
(0.162)\end{array}$ & $(0.178)$ & $\begin{array}{c}0.245 \\
(0.164)\end{array}$ & $(0.176)$ \\
\hline CONSUMER ELECTRONICS & $\begin{array}{c}0.053 \\
(0.743)\end{array}$ & $(0.160)$ & $\begin{array}{c}0.065 \\
(0.686)\end{array}$ & $(0.160)$ & $\begin{array}{c}0.029 \\
(0.861)\end{array}$ & $(0.167)$ & $\begin{array}{c}0.004 \\
(0.982)\end{array}$ & $(0.167)$ & $\begin{array}{c}0.044 \\
(0.796)\end{array}$ & $(0.170)$ & $\begin{array}{c}0.053 \\
(0.803)\end{array}$ & $(0.170)$ & $\begin{array}{c}0.057 \\
(0.737)\end{array}$ & $(0.171)$ & $\begin{array}{c}0.038 \\
(0.823)\end{array}$ & $(0.171)$ \\
\hline $\mathrm{N}$ & \multicolumn{2}{|c|}{849} & \multicolumn{2}{|c|}{848} & \multicolumn{2}{|c|}{814} & \multicolumn{2}{|c|}{814} & \multicolumn{2}{|c|}{749} & \multicolumn{2}{|c|}{749} & \multicolumn{2}{|c|}{749} & \multicolumn{2}{|c|}{749} \\
\hline -2 Log Likelihood & \multicolumn{2}{|c|}{5458.7} & \multicolumn{2}{|c|}{5450.6} & \multicolumn{2}{|c|}{5292.4} & \multicolumn{2}{|c|}{5274.3} & \multicolumn{2}{|c|}{5039.0} & 50 & & & & & \\
\hline Chi-Square & & & & & 55 & & 74. & & & & 84 & & & & & \\
\hline
\end{tabular}

These variables correspond to EXPERIENCE_DEPTH. 
Table V: COX proportional hazard of re-entry within 10 years

\begin{tabular}{|c|c|c|c|c|c|c|c|c|c|c|c|c|c|c|c|c|}
\hline \multirow[t]{2}{*}{ Variables } & \multicolumn{2}{|c|}{ Model 1} & \multicolumn{2}{|c|}{ Model 2} & \multicolumn{2}{|c|}{ Model 3} & \multicolumn{2}{|c|}{ Model 4} & \multicolumn{2}{|c|}{ Model 5} & \multicolumn{2}{|c|}{ Model 6} & \multicolumn{2}{|c|}{ Model 7} & \multicolumn{2}{|c|}{ Model 8} \\
\hline & $\begin{array}{c}\beta \\
(\text { sig. })\end{array}$ & S.E. & $\begin{array}{c}\beta \\
(\text { sig.) }\end{array}$ & S.E. & $\begin{array}{c}\beta \\
(\text { sig.) }\end{array}$ & S.E. & $\begin{array}{c}\beta \\
(\text { sig.) }\end{array}$ & S.E. & $\begin{array}{c}\beta \\
\text { (sig.) }\end{array}$ & S.E. & $\begin{array}{c}\beta \\
\text { (sig.) }\end{array}$ & S.E. & $\begin{array}{c}\beta \\
(\text { sig.) }\end{array}$ & S.E. & $\begin{array}{c}\beta \\
(\text { sig. })\end{array}$ & S.E. \\
\hline EXPERIENCE_LENGTH & & & $\begin{array}{c}-0.008 \\
(0.003)\end{array}$ & $(0.003)$ & $\begin{array}{l}-0.007 \\
(0.009)\end{array}$ & $(0.003)$ & $\begin{array}{c}-0.004 \\
(0.116)\end{array}$ & $(0.003)$ & $\begin{array}{r}-0.005 \\
(0.085)\end{array}$ & $(0.003)$ & $\begin{array}{r}-0.005 \\
(0.055)\end{array}$ & $(0.003)$ & $\begin{array}{c}-0.004 \\
(0.100)\end{array}$ & $(0.003)$ & $\begin{array}{r}-0.004 \\
(0.123)\end{array}$ & $(0.003)$ \\
\hline EXPORTS vs. JV ${ }^{\mathrm{a}}$ & & & & & $\begin{array}{r}-0.351 \\
(0.002)\end{array}$ & $(0.113)$ & $\begin{array}{c}0.237 \\
(0.043)\end{array}$ & $(0.117)$ & $\begin{array}{r}-0.240 \\
(0.044)\end{array}$ & $(0.120)$ & $\begin{array}{c}0.243 \\
(0.042)\end{array}$ & $(0.120)$ & $\begin{array}{r}-0.250 \\
(0.038)\end{array}$ & $(0.121)$ & $\begin{array}{c}0.219 \\
(0.075)\end{array}$ & $(0.123)$ \\
\hline NONEQ_ALLIANCES vs. JV ${ }^{\mathrm{a}}$ & & & & & $\begin{array}{l}-0.445 \\
(0.001)\end{array}$ & $(0.137)$ & $\begin{array}{c}0.422 \\
(0.003)\end{array}$ & $(0.141)$ & $\begin{array}{r}-0.505 \\
(0.001)\end{array}$ & $(0.146)$ & $\begin{array}{c}0.499 \\
(0.001)\end{array}$ & $(0.146)$ & $\begin{array}{l}-0.417 \\
(0.004)\end{array}$ & $(0.146)$ & $\begin{array}{c}0.471 \\
(0.001)\end{array}$ & $(0.147)$ \\
\hline WOS vs. JV & & & & & $\begin{array}{l}-0.607 \\
(0.000)\end{array}$ & $(0.125)$ & $\begin{array}{c}0.438 \\
(0.001)\end{array}$ & $(0.131)$ & $\begin{array}{l}-0.362 \\
(0.006)\end{array}$ & $(0.131)$ & $\begin{array}{c}0.378 \\
(0.004)\end{array}$ & $(0.132)$ & $\begin{array}{r}-0.379 \\
(0.004)\end{array}$ & $(0.132)$ & $\begin{array}{c}0.343 \\
(0.010)\end{array}$ & $(0.133)$ \\
\hline POORMKT_PERFORMANCE ${ }^{\mathrm{b}}$ & & & & & & & $\begin{array}{c}0.639 \\
(0.000)\end{array}$ & $(0.126)$ & $\begin{array}{c}0.304 \\
(0.000)\end{array}$ & $(0.044)$ & $\begin{array}{c}0.137 \\
(0.202)\end{array}$ & $(0.107)$ & $\begin{array}{c}0.177 \\
(0.094)\end{array}$ & $(0.106)$ & $\begin{array}{c}0.162 \\
(0.127)\end{array}$ & $(0.106)$ \\
\hline POORMODE_PERFORMANCE ${ }^{\mathrm{b}}$ & & & & & & & $\begin{array}{c}0.428 \\
(0.000)\end{array}$ & $(0.103)$ & $\begin{array}{c}0.147 \\
(0.001)\end{array}$ & $(0.043)$ & $\begin{array}{r}-0.416 \\
(0.001)\end{array}$ & $(0.126)$ & $\begin{array}{c}0.457 \\
(0.000)\end{array}$ & $(0.126)$ & $\begin{array}{c}0.429 \\
(0.001)\end{array}$ & $(0.128)$ \\
\hline INST_QUAL (1) & & & & & & & & & $\begin{array}{c}0.289 \\
(0.000)\end{array}$ & $(0.046)$ & $\begin{array}{c}0.272 \\
(0.000)\end{array}$ & $(0.059)$ & $\begin{array}{l}-0.501 \\
(0.059)\end{array}$ & $(0.266)$ & $\begin{array}{c}0.130 \\
(0.363)\end{array}$ & $(0.143)$ \\
\hline INST_QUAL (2) & & & & & & & & & $\begin{array}{c}0.142 \\
(0.001)\end{array}$ & $(0.043)$ & $\begin{array}{l}0.040 \\
(0.493)\end{array}$ & $(0.058)$ & $\begin{array}{c}0.060 \\
(0.807)\end{array}$ & $(0.246)$ & $\begin{array}{c}0.001 \\
(0.994)\end{array}$ & $(0.138)$ \\
\hline $\begin{array}{l}\text { INST_QUAL (1) } \mathrm{x} \\
\text { EXPERIENCE_LENGTH }\end{array}$ & & & & & & & & & & & $\begin{array}{c}0.001 \\
(0.807)\end{array}$ & $(0.002)$ & & & & \\
\hline $\begin{array}{l}\text { INST_QUAL }(\overline{2}) \mathrm{x} \\
\text { EXPERIENCE LENGTH }\end{array}$ & & & & & & & & & & & $\begin{array}{c}0.007 \\
(0.013)\end{array}$ & $(0.003)$ & & & & \\
\hline $\begin{array}{l}\text { INST_QUAL (1) x EXPORTS vs. } \\
J^{\mathrm{a}}{ }^{\mathrm{a}}\end{array}$ & & & & & & & & & & & & & $\begin{array}{r}-0.296 \\
(0.024)\end{array}$ & $(0.132)$ & & \\
\hline $\begin{array}{l}\text { INST_QUAL (1) x } \\
\text { NONEQ_ALLIANCES vs. JV }\end{array}$ & & & & & & & & & & & & & $\begin{array}{l}-0.550 \\
(0.000)\end{array}$ & $(0.150)$ & & \\
\hline INST_QUAL (1) x WOS vs. JV & & & & & & & & & & & & & $\begin{array}{r}-0.211 \\
(0.114)\end{array}$ & $(0.134)$ & & \\
\hline $\begin{array}{l}\text { INST_QUAL (2) x EXPORTS vs. } \\
J^{\mathrm{a}}\end{array}$ & & & & & & & & & & & & & $\begin{array}{r}-0.029 \\
(0.815)\end{array}$ & $(0.124)$ & & \\
\hline $\begin{array}{l}\text { INST_QUAL (2) x } \\
\text { NONEQ_ALLIANCES vs. JV }\end{array}$ & & & & & & & & & & & & & $\begin{array}{l}-0.114 \\
(0.382)\end{array}$ & $(0.131)$ & & \\
\hline INST_QUAL (2) x WOS vs. JV & & & & & & & & & & & & & $\begin{array}{c}0.027 \\
(0.838)\end{array}$ & $(0.134)$ & & \\
\hline $\begin{array}{l}\text { INST_QUAL (1) x } \\
\text { POORMKT_PERFORMANCE }\end{array}$ & & & & & & & & & & & & & & & $\begin{array}{r}-0.134 \\
(0.171)\end{array}$ & $(0.098)$ \\
\hline $\begin{array}{l}\text { INST_QUAL (1) x } \\
\text { POORMODE_PERFORMANCE }\end{array}$ & & & & & & & & & & & & & & & $\begin{array}{l}-0.103 \\
(0.415)\end{array}$ & $(0.126)$ \\
\hline $\begin{array}{l}\text { INST_QUAL_(2) x } \\
\text { POORMKT_PERFORMANCE }\end{array}$ & & & & & & & & & & & & & & & $\begin{array}{r}-0.164 \\
(0.113)\end{array}$ & $(0.103)$ \\
\hline $\begin{array}{l}\text { INST_QUĀ }(2) \mathrm{x} \\
\text { POORMODE_PERFORMANCE } \\
\text { Controls }\end{array}$ & & & & & & & & & & & & & & & $\begin{array}{l}-0.077 \\
(0.541)\end{array}$ & $(0.126)$ \\
\hline LNSIZE & $\begin{array}{l}-0.120 \\
(0.000)\end{array}$ & $(0.033)$ & $\begin{array}{l}-0.119 \\
(0.000)\end{array}$ & $(0.033)$ & $\begin{array}{l}-0.109 \\
(0.001)\end{array}$ & $(0.034)$ & $\begin{array}{l}-0.105 \\
(0.002)\end{array}$ & $(0.034)$ & $\begin{array}{l}-0.094 \\
(0.007)\end{array}$ & $(0.035)$ & $\begin{array}{l}-0.099 \\
(0.005)\end{array}$ & $(0.035)$ & $\begin{array}{l}-0.084 \\
(0.018)\end{array}$ & $(0.036)$ & $\begin{array}{l}-0.092 \\
(0.009)\end{array}$ & 0.035 \\
\hline AGE & $\begin{array}{c}0.002 \\
(0.083)\end{array}$ & $(0.001)$ & $\begin{array}{c}0.002 \\
(0.049)\end{array}$ & $(0.001)$ & $\begin{array}{c}0.001 \\
(0.201)\end{array}$ & $(0.001)$ & $\begin{array}{c}0.001 \\
(0.131)\end{array}$ & $(0.001)$ & $\begin{array}{c}0.001 \\
(0.155)\end{array}$ & $(0.001)$ & $\begin{array}{c}0.001 \\
(0.212)\end{array}$ & $(0.001)$ & $\begin{array}{c}0.002 \\
(0.146)\end{array}$ & $(0.001)$ & $\begin{array}{c}0.001 \\
(0.178)\end{array}$ & $(0.001)$ \\
\hline NCOUNTRY_INT & $\begin{array}{c}0.001 \\
(0.301)\end{array}$ & $(0.001)$ & $\begin{array}{c}0.001 \\
(0.441)\end{array}$ & $(0.001)$ & $\begin{array}{c}0.001 \\
(0.442)\end{array}$ & $(0.001)$ & $\begin{array}{c}0.002 \\
(0.137)\end{array}$ & $(0.001)$ & $\begin{array}{c}0.002 \\
(0.056)\end{array}$ & $(0.001)$ & $\begin{array}{c}0.002 \\
(0.054)\end{array}$ & $(0.001)$ & $\begin{array}{c}0.002 \\
(0.067)\end{array}$ & $(0.001)$ & $\begin{array}{c}0.002 \\
(0.054)\end{array}$ & $(0.001)$ \\
\hline NCOUNTRY_HOST & $\begin{array}{l}-0.011 \\
(0.070)\end{array}$ & $(0.006)$ & $\begin{array}{l}-0.012 \\
(0.061)\end{array}$ & $(0.006)$ & $\begin{array}{l}-0.012 \\
(0.064)\end{array}$ & $(0.006)$ & $\begin{array}{l}-0.013 \\
(0.048)\end{array}$ & $(0.006)$ & $\begin{array}{l}-0.006 \\
(0.348)\end{array}$ & $(0.006)$ & $\begin{array}{l}-0.006 \\
(0.333)\end{array}$ & $(0.006)$ & $\begin{array}{l}-0.007 \\
(0.304)\end{array}$ & $(0.006)$ & $\begin{array}{l}-0.005 \\
(0.412)\end{array}$ & $(0.006)$ \\
\hline NYEARS & $\begin{array}{l}-0.119 \\
(0.033)\end{array}$ & $(0.056)$ & $\begin{array}{l}-0.046 \\
(0.444)\end{array}$ & $(0.060)$ & $\begin{array}{l}-0.022 \\
(0.717)\end{array}$ & $(0.061)$ & $\begin{array}{l}-0.052 \\
(0.393)\end{array}$ & $(0.061)$ & $\begin{array}{l}-0.006 \\
(0.918)\end{array}$ & $(0.062)$ & $\begin{array}{c}0.001 \\
(0.983)\end{array}$ & $(0.062)$ & $\begin{array}{l}-0.010 \\
(0.874)\end{array}$ & $(0.063)$ & $\begin{array}{r}-0.006 \\
(0.926)\end{array}$ & $(0.062)$ \\
\hline REG & $\begin{array}{c}0.076 \\
(0.392)\end{array}$ & $(0.089)$ & $\begin{array}{c}0.068 \\
(0.448)\end{array}$ & $(0.089)$ & $\begin{array}{c}0.061 \\
(0.498)\end{array}$ & $(0.091)$ & $\begin{array}{c}0.071 \\
(0.434)\end{array}$ & $(0.091)$ & $\begin{array}{c}0.115 \\
(0.216)\end{array}$ & $(0.093)$ & $\begin{array}{c}0.132 \\
(0.160)\end{array}$ & $(0.094)$ & $\begin{array}{c}0.084 \\
(0.368)\end{array}$ & $(0.094)$ & $\begin{array}{c}0.100 \\
(0.290)\end{array}$ & $(0.094)$ \\
\hline PRIOR_PRESENCE & $\begin{array}{c}0.236 \\
(0.018)\end{array}$ & $(0.100)$ & $\begin{array}{c}0.236 \\
(0.018)\end{array}$ & $(0.099)$ & $\begin{array}{c}0.200 \\
(0.048)\end{array}$ & $(0.101)$ & $\begin{array}{c}0.120 \\
(0.244)\end{array}$ & $(0.103)$ & $\begin{array}{l}-0.073 \\
(0.495)\end{array}$ & $(0.106)$ & $\begin{array}{l}-0.076 \\
(0.474)\end{array}$ & $(0.107)$ & $\begin{array}{c}-0.093 \\
(0.391)\end{array}$ & $(0.108)$ & $\begin{array}{l}-0.082 \\
(0.444)\end{array}$ & $(0.107)$ \\
\hline AUTOMOTIVE & $\begin{array}{l}-0.141 \\
(0.261)\end{array}$ & $(0.126)$ & $\begin{array}{l}-0.120 \\
(0.342)\end{array}$ & $(0.127)$ & $\begin{array}{l}-0.239 \\
(0.071)\end{array}$ & $(0.132)$ & $\begin{array}{l}-0.334 \\
(0.013)\end{array}$ & $(0.134)$ & $\begin{array}{l}-0.344 \\
(0.013)\end{array}$ & $(0.137)$ & $\begin{array}{l}-0.343 \\
(0.014)\end{array}$ & $(0.139)$ & $\begin{array}{c}-0.339 \\
(0.014)\end{array}$ & $(0.139)$ & $\begin{array}{l}-0.354 \\
(0.011)\end{array}$ & $(0.140)$ \\
\hline RETAIL & $\begin{array}{l}-0.050 \\
(0.713)\end{array}$ & $(0.137)$ & $\begin{array}{l}-0.056 \\
(0.682)\end{array}$ & $(0.137)$ & $\begin{array}{l}-0.012 \\
(0.933)\end{array}$ & $(0.143)$ & $\begin{array}{c}-0.098 \\
(0.483)\end{array}$ & $(0.139)$ & $\begin{array}{l}-0.179 \\
(0.208)\end{array}$ & $(0.142)$ & $\begin{array}{c}-0.184 \\
(0.194)\end{array}$ & $(0.142)$ & $\begin{array}{l}-0.195 \\
(0.175)\end{array}$ & $(0.143)$ & $\begin{array}{l}-0.172 \\
(0.226)\end{array}$ & $(0.142)$ \\
\hline FINANCIAL SERVICES & $\begin{array}{l}-0.061 \\
(0.648)\end{array}$ & $(0.134)$ & $\begin{array}{c}0.001 \\
(0.994)\end{array}$ & $(0.134)$ & $\begin{array}{l}-0.017 \\
(0.903)\end{array}$ & $(0.143)$ & $\begin{array}{c}0.068 \\
(0.639)\end{array}$ & $(0.144)$ & $\begin{array}{c}0.200 \\
(0.177)\end{array}$ & $(0.147)$ & $\begin{array}{c}0.185 \\
(0.213)\end{array}$ & $(0.149)$ & $\begin{array}{c}0.185 \\
(0.216)\end{array}$ & $(0.150)$ & $\begin{array}{c}0.217 \\
(0.145)\end{array}$ & $(0.149)$ \\
\hline CONSUMER ELECTRONICS & $\begin{array}{c}0.246 \\
(0.051)\end{array}$ & $(0.126)$ & $\begin{array}{c}0.253 \\
(0.044)\end{array}$ & $(0.125)$ & $\begin{array}{c}0.227 \\
(0.084)\end{array}$ & $(0.131)$ & $\begin{array}{c}0.204 \\
(0.120)\end{array}$ & $(0.131)$ & $\begin{array}{c}0.243 \\
(0.071)\end{array}$ & $(0.134)$ & $\begin{array}{c}0.238 \\
(0.078)\end{array}$ & $(0.135)$ & $\begin{array}{c}0.262 \\
(0.053)\end{array}$ & $(0.135)$ & $\begin{array}{c}0.252 \\
(0.064)\end{array}$ & $(0.136)$ \\
\hline $\mathrm{N}$ & \multicolumn{2}{|c|}{849} & \multicolumn{2}{|c|}{848} & \multicolumn{2}{|c|}{814} & \multicolumn{2}{|c|}{814} & \multicolumn{2}{|c|}{749} & \multicolumn{2}{|c|}{749} & \multicolumn{2}{|c|}{749} & \multicolumn{2}{|c|}{749} \\
\hline -2 Log Likelihood & \multicolumn{2}{|c|}{7903.7} & \multicolumn{2}{|c|}{7893.1} & \multicolumn{2}{|c|}{7543.6} & \multicolumn{2}{|c|}{7514.4} & \multicolumn{2}{|c|}{7125.6} & \multicolumn{2}{|c|}{7118.9} & & & & \\
\hline Chi-Square & & & $\begin{array}{l}54 \\
(0 .\end{array}$ & & $\begin{array}{l}74.1 \\
(0.0\end{array}$ & & $\begin{array}{l}104 . \\
(0.0\end{array}$ & & $\begin{array}{l}114 . \\
(0.0\end{array}$ & & $\begin{array}{l}116 \\
(0.6\end{array}$ & & & & & \\
\hline
\end{tabular}

These variables correspond to EXPERIENCE_DEPTH.
bThese variables correspond to EXPERIENCE NATURE. 


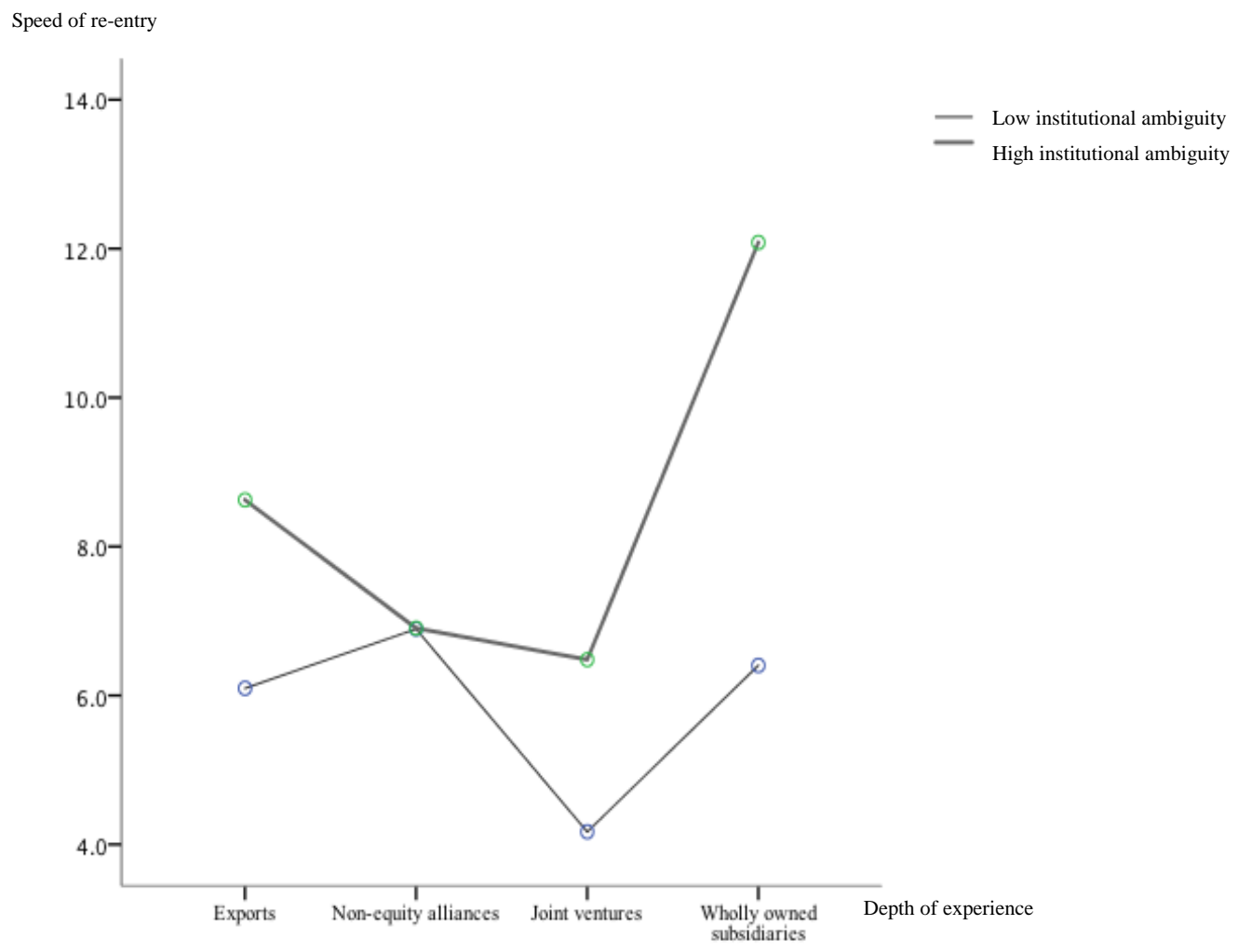

Figure II. Interaction effect between depth of experience and host institutional ambiguity

N.B.: Low (high) depth of experience and low (high) host institutional ambiguity correspond to values below (above) the mean minus (plus) half of a standard deviation. 